\title{
Secondary Production of Benthic Insects in Three Cold-Desert Streams
}

W. L. Gaines

July 1987

Prepared for the U.S. Department of Energy under Contract DE-AC06-76RLO 1830

Pacific Northwest Laboratory Operated for the U.S. Department of Energy by Battelle Memorial Institute 


\section{DISCLAIMER}

This report was prepared as an account of work sponsored by an agency of the United States Government. Neither the United States Government nor any agency thereof, nor Battelle Memorial Institute, nor any of their employees, makes any warranty, expressed or implied, or assumes any legal liability or responsibility for the accuracy, completeness, or usefulness of any information, apparatus, product, or process disclosed, or represents that its use would not infringe privately owned rights. Reference herein to any specific commercial product, process, or service by trade name, trademark, manufacturer, or otherwise, does not necessarily constitute or imply its endorsement, recommendation, or favoring by the United States Government of any agency thereof, or Battelle Memorial Institute. The views and opinions of authors expressed herein do not necessarly state or reflect those of the United States Government or any agency thereof, or Battelle Memorial Institute.

\section{PACIFIC NORTHWEST LABORATORY operated by \\ BATTELLE MEMORIAL INSTITUTE for the \\ UNITED STATES DEPARTMENT OF ENERGY under Contract DE-AC06-76RLO 1830}

\begin{tabular}{|c|c|}
\hline \multicolumn{2}{|c|}{ Printed in the United States of America } \\
\hline \multirow{2}{*}{\multicolumn{2}{|c|}{$\begin{array}{c}\text { Available from } \\
\text { National Technical Information Service }\end{array}$}} \\
\hline \multirow{4}{*}{\multicolumn{2}{|c|}{$\begin{array}{c}\text { National Technical Information Service } \\
\text { United States Department of Commerce } \\
\text { 5285 Port Royal Road } \\
\text { Springfield, Virginia 22161 }\end{array}$}} \\
\hline & \\
\hline & \\
\hline & \\
\hline \multirow{2}{*}{\multicolumn{2}{|c|}{$\begin{array}{l}\text { NTIS Price Codes } \\
\text { Microfiche A01 }\end{array}$}} \\
\hline & \\
\hline \multicolumn{2}{|c|}{ Printed Copy } \\
\hline & Price \\
\hline Pages & Codes \\
\hline $001-025$ & $\mathrm{~A} 02$ \\
\hline $026-050$ & $\mathrm{AO}_{3}$ \\
\hline $051-075$ & $\mathrm{~A} 04$ \\
\hline $076-100$ & A05 \\
\hline $101-125$ & A. 6 \\
\hline $126-150$ & 17 \\
\hline $151-175$ & A08 \\
\hline $176-200$ & A09 \\
\hline $201-225$ & A010 \\
\hline $226-250$ & A011 \\
\hline $251-275$ & $\mathrm{~A} 012$ \\
\hline $276-300$ & A013 \\
\hline
\end{tabular}


SECONDARY PRODUCTION OF BENTHIC INSECTS

IN THREE COLD-DESERT STREAMS

W. L. Gaines

July 1987

Prepared for the U.S. Department of Energy under Contract DE-ACO6-76RLO 1830

Pacific Northwest Laboratory Richland, Washington 99352 




..

\section{I}


SUMMARY

I studied aquatic insect production in three cold-desert streams in eastern Washington (Douglas Creek, Snively Springs, and Rattlesnake Springs). The size-frequency method was applied to individual taxa to estimate total insect production. Production was also assessed for functional groups and trophic levels in each stream.

Optioservus sp. (riffle beetles) and Baetis sp. (mayflies) accounted for $72 \%$ of the total insect numbers and $50 \%$ of the total biomass in Douglas Creek. Baetis sp. accounted for $42 \%$ of the total insect numbers and $25 \%$ of the total biomass in Snively Springs. Simulium sp. (blackflies) and Baetis sp. comprised $74 \%$ of the total insect numbers and $55 \%$ of the total biomass in Rattlesnake Springs.

Grazer-scrapers (49\%) and collectors (48\%) were the most abundant functional groups in Douglas Creek. Collectors were the most abundant functional group in Snively Springs and Rattlesnake Springs. Herbivores and detritivores were the most abundant trophic level in Snively Springs and Rattlesnake Springs.

Dipterans (midges and blackflies) were the most productive taxa within the study streams, accounting for $40 \%$ to $70 \%$ of the tota 1 community production. Production by collectors and detritivores was the highest of all functional groups and trophic levels in all study streams.

Insects with rapid development times and multiple cohorts were very important in cold-desert streams, contributing significantly to the total community production. Total community production rates were generally higher than in northern temperate streams, lower than in southeastern blackwater streams, and much lower than in Sonoran Desert streams. Much of the production in cold-desert streams can be attributed to insects feeding upon detritus, and detritus was obtained by collecting (filtering and gathering). I suggest that production, not 
density or biomass, is the most accurate and meaningful way to assess the roles of organisms in aquatic ecosystems, and that the procedure given by Benke et al. (1984) should be followed to calculate production. 


\section{ACKNOWLEOGMENTS}

I am grateful to Dr. Stamford D. Smith and Or. Colbert E. Cushing for their support and advice throughout this research project. I am especially grateful for their constructive comments on this manuscript. I would like to thank Dr. William Coffman for identifying the chironomids and Dr. Pat Schefter for identifying the caddisflies. Dr. Lee Rogers kindly provided space for laboratory and office work.

This research was originally presented in a master's thesis for Central Washington University. The research was performed at Pacific Northwest Laboratory during a Northwest College and University Association for Science (NORCUS) Fellowship (University of Washington), funded under Contract DE-AM06-76-RL02225. This work was supported by the U.S. Department of Energy under Contract DE-AC06-76RLO 1830. Pacific Northwest Laboratory is operated for the U.S. Department of Energy by Battelle Memorial Institute. 
CONTENTS

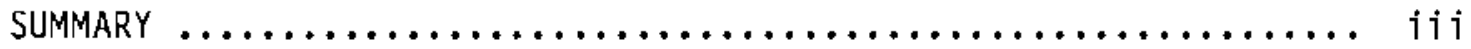

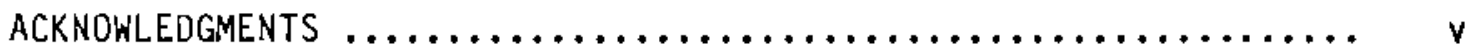

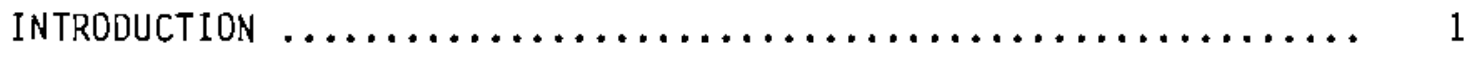

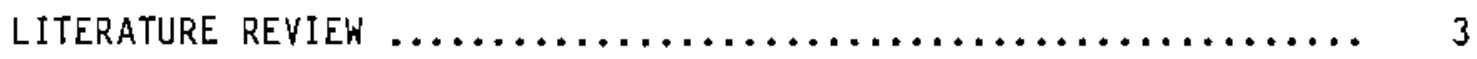

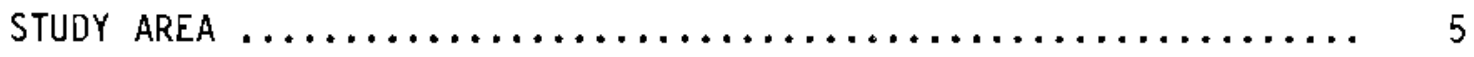

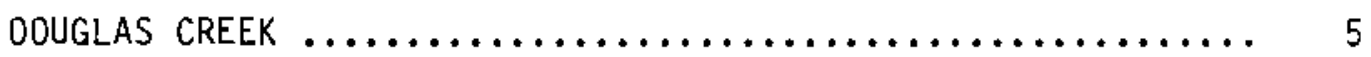

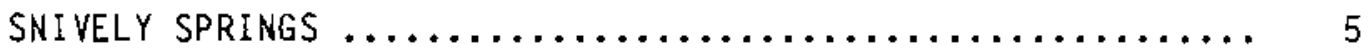

RATTLESNAKE SPRINGS $\ldots \ldots \ldots \ldots \ldots \ldots \ldots \ldots \ldots \ldots \ldots \ldots \ldots, 7$

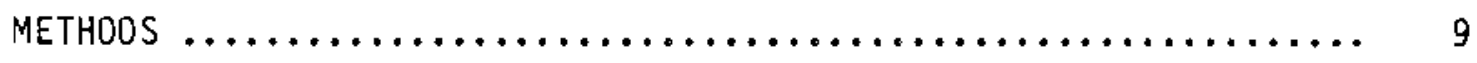

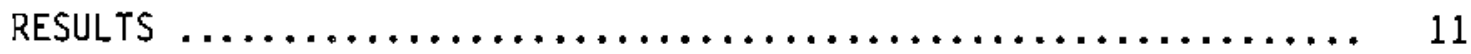

INSECT DENSITY AND BIOMASS $\ldots \ldots \ldots \ldots \ldots \ldots \ldots \ldots \ldots \ldots, 11$

Douglas Creek $\ldots \ldots \ldots \ldots \ldots \ldots \ldots \ldots \ldots \ldots \ldots \ldots \ldots, 11$

Snively Springs $\ldots \ldots \ldots \ldots \ldots \ldots \ldots \ldots \ldots \ldots \ldots \ldots, 11$

Rattlesnake Springs $\ldots \ldots \ldots \ldots \ldots \ldots \ldots \ldots \ldots \ldots \ldots, 11$

FUNCTIONAL GROUP DENSITY ANO BIOMASS $\ldots \ldots \ldots \ldots \ldots \ldots \ldots \ldots . .11$

Douglas Creek $. . \ldots \ldots \ldots \ldots \ldots \ldots \ldots \ldots \ldots \ldots \ldots \ldots, 11$

Snively Springs $\ldots \ldots \ldots \ldots \ldots \ldots \ldots \ldots \ldots \ldots \ldots \ldots, 13$

Rattlesnake Springs $\ldots \ldots \ldots \ldots \ldots \ldots \ldots \ldots \ldots \ldots \ldots, 16$

TROPHIC LEYEL DENSITY AND BIOMASS $\ldots \ldots \ldots \ldots \ldots \ldots \ldots \ldots, 18$

Douglas Creek $\ldots \ldots \ldots \ldots \ldots \ldots \ldots \ldots \ldots \ldots \ldots \ldots \ldots, 18$

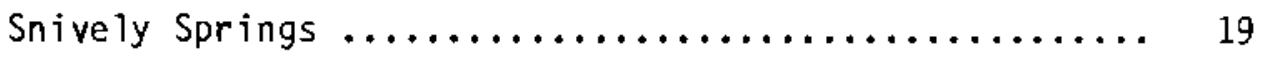

Rattlesnake Springs $\ldots \ldots \ldots \ldots \ldots \ldots \ldots \ldots \ldots \ldots \ldots, 19$

INSECT PRODUCTION $\ldots \ldots \ldots \ldots \ldots \ldots \ldots \ldots \ldots \ldots \ldots \ldots \ldots, 20$

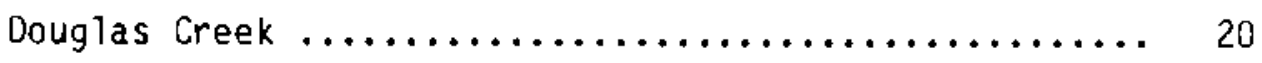




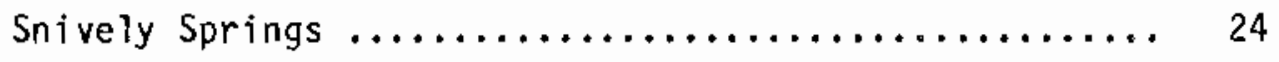

Rattlesnake Springs $\ldots \ldots \ldots \ldots \ldots \ldots \ldots \ldots \ldots \ldots \ldots, 26$

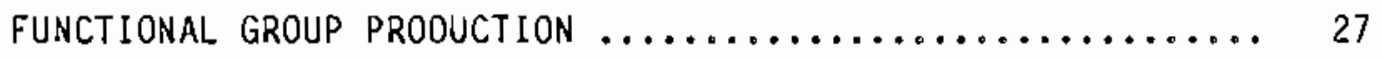

TROPHIC LEVEL PRODUCTION ......................... 29

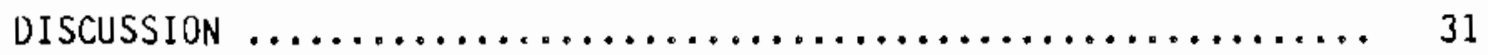

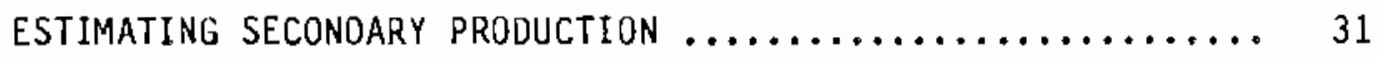

COMPARISON BETHEEN STUOY STREAMS $\ldots \ldots \ldots \ldots \ldots \ldots \ldots \ldots \ldots \ldots \ldots \ldots \ldots$

Insect Faunas $\ldots \ldots \ldots \ldots \ldots \ldots \ldots \ldots \ldots \ldots \ldots \ldots \ldots \ldots, \quad 31$

Functionai Groups and Trophic Levels ............ 32

COMPARISON WITH OTHER STREAMS $\ldots \ldots \ldots \ldots \ldots \ldots \ldots \ldots \ldots \ldots \ldots \ldots \ldots$

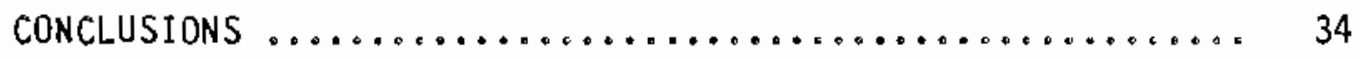

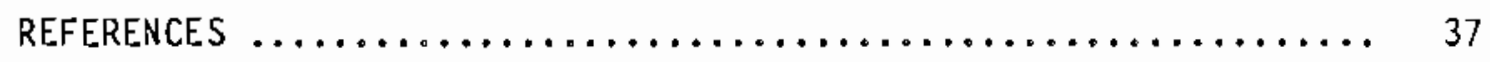




\section{FIGURES}

1 Temperature Regime for Douglas Creek .................. 6

2 Temperature Regime for Snively Springs $\ldots \ldots \ldots \ldots \ldots \ldots \ldots$

3 Temperature Regime for Rattlesnake Springs $\ldots \ldots \ldots \ldots \ldots \ldots$...... 8 
TABLES

1 Substrate Composition of Douglas Creek, Snively Springs,

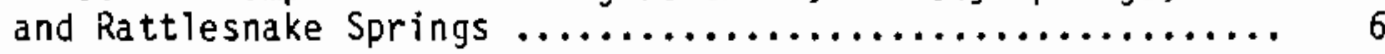

2 Annual Mean Density and Biomass of Insects from Douglas Creek .................................. 12

3 Annual Mean Density and Biomass of Insects from Snively Springs

4 Annual Mean Density and Biomass of Insects from

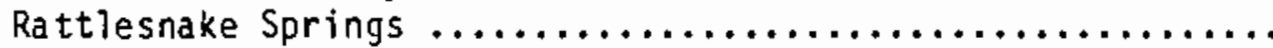

5 Results of Qualitative Gut Content Analysis and Subsequent Functional Group and Trophic Level Classification for Insects from Douglas Creek .............................

6 Results of Qualitative Gut Content Analysis and Subsequent Functional Group and Trophic Level Classification of Insects from Snively Springs

7 ResuTts of Qualitative Gut Content AnaTysis and Subsequent Functional Group and Trophic Level Classification of

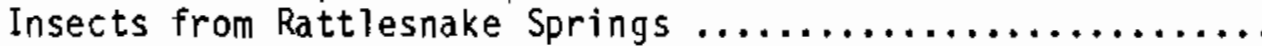

8 Annual Mean Density and Biomass of Insect Functional Groups

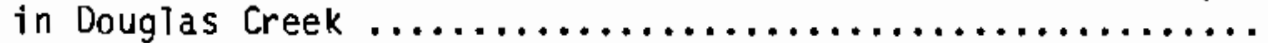

9 Annual Mean Density and Biomass of Insect Functional Groups



10 Annual Mean Density and Biomass of Insect Functional Groups

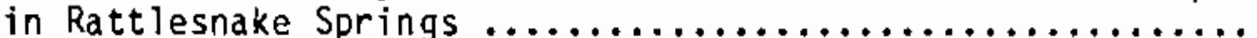

11 Annual Mean Density and Biomass of Insect Trophic Levels in

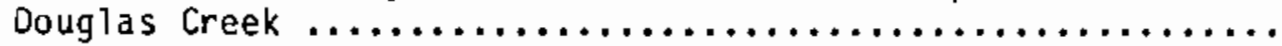

12 Annual Mean Density and Biomass of Insect Trophic Leveis in

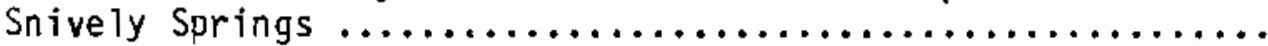

13 Annual Mean Density and Biomass of Insect Trophic Levels in

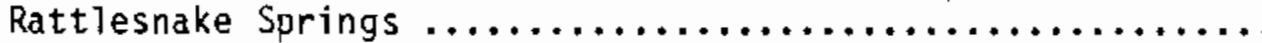

14 Annual Production of Insects from Douglas Creek,

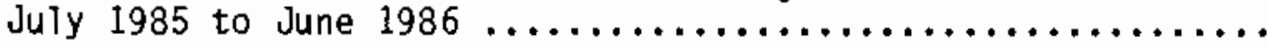

15 Annual Production of Insects from Snively Springs, July 1985 to June 1986 
16 Annual Production of Insects from Rattlesnake Springs,

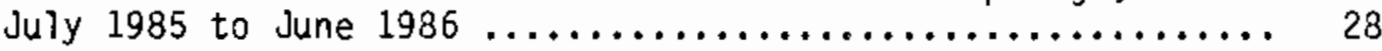

17 Annual Production of Insect Functional Groups in Douglas Creek, Snively Springs, and Rattlesnake Springs ...............

18 Annual Production of lnsect Trophic Levels in Douglas Creek, Snively Springs, and Rattlesnake Springs ................ 30 


\section{INTRODUCTION}

Secondary production is defined as the rate of animal tissue elaboration over time regardless of the fate (carnivory, emergence, etc.) of that production (Benke and Wallace 1980). Estimating secondary production within a stream provides an assessment of the roles of animals within the ecosystem (Benke and Wallace 1980) while gaining insight into ecosystem dynamics.

Studies dealing only with density and biomass values may not accurately describe the roles of aquatic organisms within the stream. Benke et al. (1984) provide an example where the importance of gatheringcollector invertebrates is underestimated by biomass analysis and overestimated by numerical analysis. Waters (1977) states that production is important to understanding ecosystem dynamics because it is the means by which energy is made available to higher trophic levels.

While most secondary production studies have focused on one or a few species within a stream (Benke and Wallace 1980, Waters and Hokenstrom 1980, 0'Hop et al. 1984), more recent studies have estimated secondary production of the entire benthic fauna (Krueger and Waters 1983, Benke et al. 1984, Smock et al. 1985). This community-level approach provides the greatest insight into the ecology of stream ecosystems.

Community-level production studies, however, have been performed on very few kinds of streams. In particular, very little is known about the secondary production of the benthic invertebrate community in desert streams. The only publications on the subject to date are those of Fisher and Gray (1983) and Jackson and Fisher (1986) on Sycamore Creek, Arizona.

I estimated the production of aquatic insects in three cold-desert streams in Washington State: Rattlesnake Springs, Snively Springs, and Douglas Creek. Ecosystem dynamics in cold-desert streams will be more fully understood by estimating the secondary production of each species, functional group, trophic level, and community. 


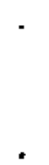




\section{LITERATURE REVIEW}

In his textbook on limnology, Welch (1935) defined his discipline as that branch of science that deals with the biological productivity of inland waters. Subsequently, scientists attempted to measure production rates of all trophic levels within an ecosystem in attempts to quantify ecosystem dynamics. Production is an important pathway of energy flow in ecosystems and is thus of great interest (Waters 1977).

Until recently, estimates of secondary production lagged behind those made of primary production. Reasons for the lag are: 1) the organisms are very diverse and some have complex $1 \mathrm{ife}$ histories;

2) large numbers of samples are needed to reduce sample variation caused by a great variation in the distribution of organisms; and 3) separating, sorting, and analyzing samples are tedious and time-consuming, thus costly, tasks. Hynes (1970) reviewed the literature through 1966 and found only four attempts at directly estimating benthic invertebrate production in streams.

Several methods have been developed to estimate secondary production in streams. The Removal-Summation, increment-Summation, Instantaneous Growth Rate, Allen Curve, and Hynes method have all been used. The Hynes method and its modifications have stood the test of time and is the most popular secondary production estimator in use today.

Originally proposed by Hynes and Coleman (1968), the Hynes method was designed as a shortcut approach to estimate production of entire benthic faunas. The method was unique in that it was not necessary to identify individual cohorts, thus making it easier to apply (Benke 1979). Hamilton (1969) modified the method by introducing the term "average cohort" when describing the size-frequency distribution that is necessary to make Hynes production estimates. Hamilton (1969) also pointed out three assumptions of the Hynes method that are difficult to justify: 1) all species in the samples are univoltine, 2) all species can potentially grow to maximum length used in the size-frequency distribution, and 3) all species require the same amount of time to grow 
through each length class. These assumptions are difficult to meet when the Hynes method is applied to species with very different life histories. Benke and Waide (1977), however, showed that many of these assumptions can be met when the method is applied to singie or similar species. Another problem that plagued the Hynes method was how to accurately estimate production of semivoltine or multivoltine populations. Benke (1979) addressed this problem by introducing the Cohort Production Interval (CPI). He suggested that the Hynes production value be rmultiplied by $365 / C P I$, where CPI is the time in days from hatching to attainment of the largest aquatic size class. A final modification was proposed by Waters' (1977) and confirmed by Hynes (1980) to change the name to the size-frequency (SF) method. This method is now commonly used by secondary production biologists and is the method I used in this study.

Recently the SF method has been used to assess secondary production of entire benthic communities (Benke et al. 1984, Jackson and Fisher 1986). Community production estimates are calculated by summing the species estimates and, in this way, accounting for variations in 1 ife histories (Benke et al. 1984). As life history data on greater numbers of species are obtained, the SF method will be more widely used and will become more accurate. 


\section{STUDY AREA}

I studied three streams in the cold-desert Physiographic Province of Eastern Washington. This shrub-steppe region is characterized by the climatic climax community of big sage (Artemesia tridentata)-bluebunch wheatgrass (Agropyron spicatum). Mean annual precipitation is approximately $14 \mathrm{~cm}$.

\section{DOUGLAS CREEK}

Douglas Creek is a spring-fed stream located in Douglas County, Washington, near the small community of Palisades, Washington. The stream drains an area of $530 \mathrm{~km}^{2}$. The lower reaches of Douglas Creek, which are used extensively for irrigation, cease to flow during dry summers. For this reason, I located all study sites in the upper reaches where flow is permanent. Riparian vegetation is dominated by water birch (Betula occidentalis) and peachleaf willow (Salix amygdaloides). Populations of crayfish (Pacifasticus lenisculus) and rainbow trout (Salmo gairdneri) inhabit this stream.

Douglas Creek is the largest of the three streams studied. The average width was $4.0 \mathrm{~m}$ and average depth was $31 \mathrm{~cm}$ during base flow. The average discharge during the study period was $0.6 \mathrm{~m}^{3} / \mathrm{s}$, and ranged from $0.5 \mathrm{~m}^{3} / \mathrm{s}$ in late summer to $0.9 \mathrm{~m}^{3} / \mathrm{s}$ in the early spring. Dissolved oxygen concentrations measured at midday ranged from a low of $9.6 \mathrm{mg} / 1$ in late summer to a high of $14.0 \mathrm{mg} / 1$ in midwinter. The temperature regime for Douglas Creek during the study period is shown in Figure 1. Table 1 shows the substrate composition of each study site.

SNIVELY SPRINGS

Snively Springs is a small spring-stream located on the U.S. Department of Energy's Hanford Site. It drains an area of approximately $40 \mathrm{~km}^{2}$. During the summer portions of the spring-stream dry up, leaving about $3.6 \mathrm{~km}$ of perennial flow. Riparian vegetation is dominated by 


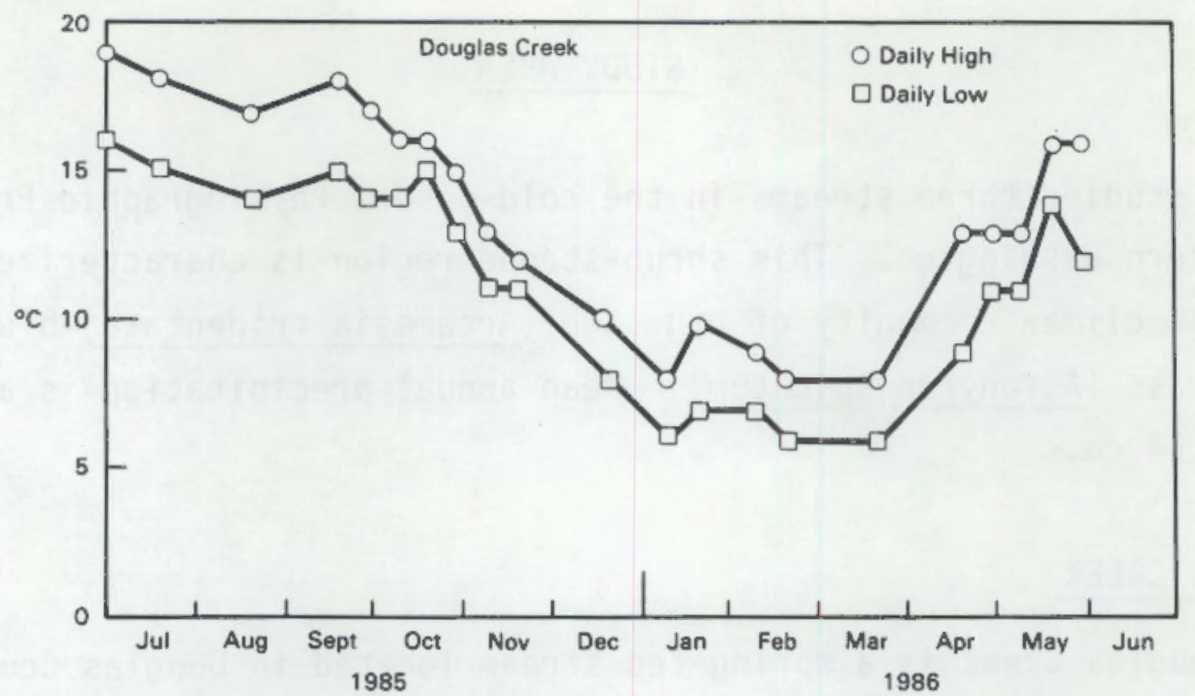

FIGURE 1. Temperature Regime for Douglas Creek

TABLE 1. Substrate Composition of Douglas Creek, Snively Springs, and Rattlesnake Springs

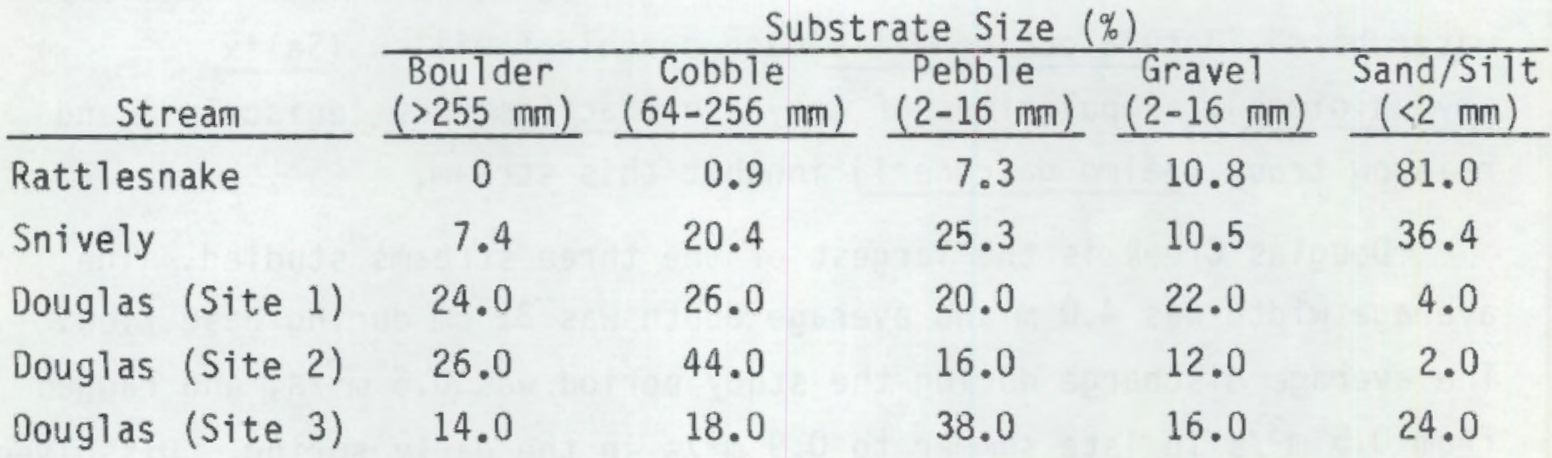

dominated by cattails (Typha latifolia) along the upper and lower reaches, and willow (Salix sp.) and wild rose (Rosa sp.) along the midreaches where it flows through a canyon. Watercress (Rorippa nasturtium-aquatica) grows extensively within the spring-stream. A small population of crayfish [(Pacifasticus lenisculus (trowbridgii)] inhabits Snively Springs.

The average width and depth of Snively Springs during base flow was $1.3 \mathrm{~m}$ and $10 \mathrm{~cm}$, respectively. Average discharge during the study period was $0.04 \mathrm{~m}^{3} / \mathrm{s}$, and ranged from $0.02 \mathrm{~m}^{3} / \mathrm{s}$ in the late spring to $0.05 \mathrm{~m}^{3 / \mathrm{s}}$ in the winter. Dissolved oxygen concentrations measured at 
midday ranged from $8.6 \mathrm{mg} / 1$ during the summer to $12.3 \mathrm{mg} / 1$ during the winter. The temperature regime for Snively Springs during the study period is shown in Figure 2, and the substrate composition is shown in Table 1.

\section{RATTLESNAKE SPRINGS}

Rattlesnake Springs is a small spring-stream also located on the U.S. Department of Energy's Hanford Site. It drains an area of $350 \mathrm{sq}$ $\mathrm{km}$ (Cushing et al. 1980). Portions of the lower reaches of the springstream dry up during the summer, leaving about $2.5 \mathrm{~km}$ of perennial flow. This spring-stream is subject to severe flash flooding during the late winter about every four years (Cushing and Wolf 1982). Riparian vegetation is dominated by peachleaf willow (Salix amygdaloides). Watercress (Rorippa nasturtium-aquatica) is the dominant in-stream autotroph, although periphyton productivity exceeded that of watercress in 1969 and 1970 (Cushing and Wolf 1984).

The average width and depth of Rattlesnake Springs during base flow was $1.7 \mathrm{~m}$ and $5 \mathrm{~cm}$, respectively. Average discharge during the study period was $0.05 \mathrm{~m}^{3} / \mathrm{s}$, and ranged from $0.03 \mathrm{~m}^{3} / \mathrm{s}$ in the spring to

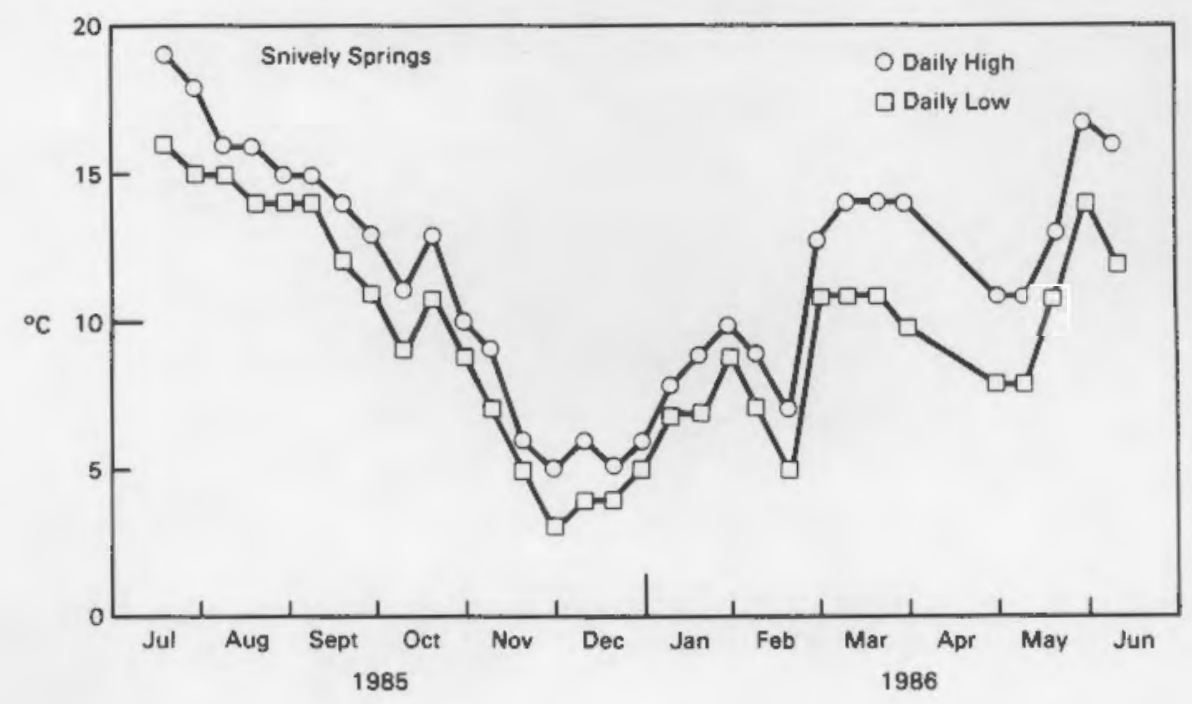

FIGURE 2. Temperature Regime for Snively Springs 
$0.07 \mathrm{~m}^{3} / \mathrm{s}$ during the winter. Midday dissolved oxygen concentrations ranged from $8.2 \mathrm{mg} / 1$ during the summer to $10.1 \mathrm{mg} / 1$ in midwinter. The temperature regime for Rattlesnake Springs during the study period is shown in Figure 3, and stream substrate composition is shown in Table 1.

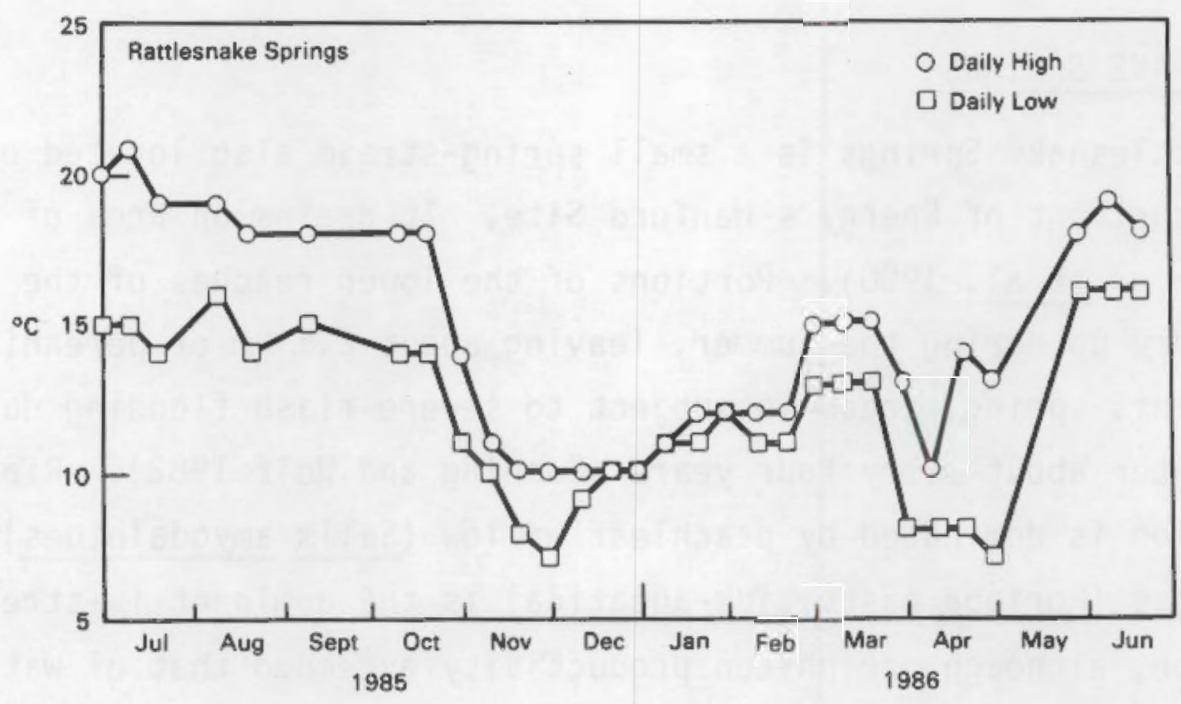

FIGURE 3. Temperature Regime for Rattlesnake Springs 
METHODS

I used a stratified random sampling regime (as recommended by Cummins 1962) in each stream to assure that a1l habitats were sampled. One study site was established in each of Snively Springs and Rattlesnake Springs, with each study site being large enough to include all habitat types. Three study sites were established in Douglas Creek: a shallow riffle (Site 1), a midsize pool and riffle (Site 2), and a large slow pool (Site 3 ).

Samples were taken at monthly intervals from July 1985 through June 1986. I collected three Surber samples $\left(0.093 \mathrm{~m}^{2} / 5\right.$ ample) from Snively Springs and Rattlesnake Springs on each sampling date. A Surber sampler was used because these spring-streams are very shallow. A Portable Invertebrate Box Sampler $\left(0.1 \mathrm{~m}^{2} / \mathrm{sample}\right)$ was used at Douglas Creek to collect one sample from Site 1, two samples from Site 2, and two samples from Site 3 on each sampling date. Fewer samples were collected from Site 1 because it was located in the upper reaches where streamflow was reduced. Douglas Creek is larger than the other study streams so the more efficient Portable Invertebrate Box Sampler was used. All samples were taken to a minimum depth of $10 \mathrm{~cm}$ and preserved in $70 \%$ ETOH for later lab analysis.

I separated insects from organic debris by sugar flotation (Anderson 1959) and sorted them into taxa. Insects were identified to the species level when possible, counted, and body length measured to the nearest 1 mol using a microscope equipped with an ocular micrometer. The trophic status of each species was determined by reference to Merritt and Cummins (1984) and examination of gut contents. Biomass [dry wt (DW)] was determined for all size classes after insects were dried at $60^{\circ} \mathrm{C}$ for 24 hours and weighed to the nearest $0.1 \mathrm{mg}$. I calculated the mean coefficient of variation ( $\mathrm{CV}$ ) and the mean standard error (SE) for all density and biomass estimates.

The SF method (Hynes and Coleman 1968, Hamilton 1969, Hynes 1980, Waters and Hokenstrom 1980) was used to estimate secondary production of 
the most common benthic insect species. An average size-frequency distribution was determined from monthly sample sets that represented the survivorship curve of an "average cohort" (Hamilton 1969, Benke and Waide 1977). Production was estimated by calculating the difference in biomass between successive size classes and then multiplying this difference by the number of size classes (Hynes and Coleman 1968, Hamilton 1969). Production estimates were refined by multiplying by $365 / \mathrm{CPI}$ (Cohort Production Interval) (Benke 1979). The CPI (Benke et al. 1984) was estimated from life history data, field observations, and in situ growth studies.

Production/bionass $(P / B)$ ratios were used to estimate secondary production for less abundant taxa. These $P / B$ ratios were either species-specific values derived from one of the other two study streams, or an assumed cohort $P / B$ value of 5 (Waters 1977, Benke et al. 1984). These taxa were not present in sufficient numbers to provide an accurate size-frequency distribution curve that is necessary to compute sizefrequency production estimates. 


\section{RESULTS}

\section{INSECT DENSITY AND BIOMASS}

Douglas Creek

Optioservus sp. (riffle beetles) and Baetis sp. (mayflies) were by far the most abundant insects found in Douglas Creek. These taxa accounted for $72 \%$ of the total insect numbers and $50 \%$ of the total biomass. Annual mean density and biomass of Dptioservus sp. Were $4322 / \mathrm{m}^{2}$ and $606.7 \mathrm{mg} \mathrm{DW} / \mathrm{m}^{2}$, respectively. Annual mean density and biomass of Baetis $s p$. were $2416 / \mathrm{m}^{2}$ and $263.7 \mathrm{mg} \mathrm{DW} / \mathrm{m}^{2}$, respectively (Table 2).

\section{Snively Springs}

Baetis sp. (mayflies) were the most numerous insects in Snively Springs, accounting for $42 \%$ of the total insect numbers and $25 \%$ of the total biomass. Annual mean density was $1388 / \mathrm{m}^{2}$ and the annual mean biomass was $185.4 \mathrm{mg} \mathrm{DW} / \mathrm{m}^{2}$ (Table 3 ).

\section{Rattlesnake Springs}

The most abundant insects in Rattlesnake Springs were Simulium sp. (blackflies) and Baetis $s p$. (mayflies). These taxa accounted for $74 \%$ of the total insect numbers and $55 \%$ of the total biomass. Annual mean density and biomass of Simulium $\mathrm{sp}$. were $1777 / \mathrm{m}^{2}$ and $212.3 \mathrm{mg} \mathrm{OW} / \mathrm{m}^{2}$, respectively. Annual mean density and biomass of Baetis $s p$. Were $1336 / \mathrm{m}^{2}$ and $47.3 \mathrm{mg} \mathrm{DW} / \mathrm{m}^{2}$, respectively (Table 4 ).

\section{FUNCTIONAL GROUP DENSITY AND BIOMASS}

Results of gut content analysis and subsequent functional group classification for insects from Douglas Creek, Snively Springs, and Rattlesnake Springs are shown in Tables 5, 6, and 7, respectively. Douglas Creek

The most abundant functional groups in Douglas Creek were grazerscrapers (49\%) and collectors (48\%). These groups accounted for $97 \%$ of 
TABLE 2. Annual Mean Density and Biomass of Insects from Douglas Creek ( $S E=$ standard error, $C V=$ coefficient of variation)

\begin{tabular}{|c|c|c|c|c|c|c|}
\hline Taxa & $\begin{array}{l}\text { ensity } \\
\left.\text { no. } / \mathrm{m}^{2}\right) \\
\end{array}$ & $\mathrm{SE} / \overrightarrow{\mathrm{X}}$ & $\mathrm{CV}$ & $\begin{array}{l}\text { Biomass } \\
\left(\mathrm{mg} / \mathrm{m}^{2}\right)\end{array}$ & $\mathrm{SE} / \overline{\mathrm{X}}$ & CV \\
\hline \multicolumn{7}{|l|}{ Diptera } \\
\hline Simulium sp. & 41 & 0.75 & 168.6 & 31.2 & 0.72 & 136.1 \\
\hline Brilla flavifrons & 12 & 0.25 & 55.0 & 0.9 & 0.26 & 57.4 \\
\hline Chironomus sp. & 753 & 0.71 & 152.3 & 60.7 & 0.69 & 153.8 \\
\hline Parametriocnemus sp. & 196 & 0.44 & 98.0 & 10.4 & 0.46 & 101.9 \\
\hline Thienemannimyia sp. & 11 & 0.81 & 180.5 & 0.9 & 0.83 & 185.4 \\
\hline Chaetocladius sp. & 115 & 0.57 & 127.8 & 3.5 & 0.66 & 129.4 \\
\hline Polypedilum sp. & 33 & 0.69 & 154.5 & 2.2 & 0.78 & 129.1 \\
\hline Geleniella sp. & 141 & 0.52 & 116.4 & 4.5 & 0.54 & 116.5 \\
\hline Phaenospectra sp. & 60 & 0.07 & 15.5 & 4.9 & 0.07 & 15.0 \\
\hline Tabanidae & 51 & 0.48 & 106.6 & 27.8 & 0.48 & 107.5 \\
\hline Tipulidae & 37 & 0.37 & 82.5 & 82.1 & 0.48 & 103.1 \\
\hline $\begin{array}{r}\text { Empididae } \\
\text { (TOTAL) }\end{array}$ & $\begin{array}{c}1 \\
(1451)\end{array}$ & 0.22 & 50.0 & $\begin{array}{c}0.1 \\
(229.2)\end{array}$ & 0.18 & 40.0 \\
\hline
\end{tabular}

Trichoptera

Leucotrichia

pictipes

hydropsyche $\mathrm{sp}$.

$\begin{array}{rrrrrr}95 & 0.63 & 139.7 & 7.7 & 0.68 & 153.2 \\ 445 & 0.57 & 127.1 & 41.3 .5 & 0.65 & 145.8 \\ 156 & 0.53 & 118.3 & 84.1 & 0.60 & 135.0 \\ 696) & & & (505.3) & & \end{array}$

Coleoptera

Optioservus $\mathrm{sp}$.

4322

0.37

83.5

606.7

$0.36 \quad 80.0$

Ephemeroptera

Leucrocuta sp.

Baetis sp.

$$
0.47 \quad 104.0
$$

92.4

51.4

$0.51 \quad 104.0$

Paraleptophlebia sp.

Tricorythodes sp.

2416

0.41

78.5

263.7

$0.41 \quad 91.9$

225

$\begin{array}{lll}6 & 0.80 \quad 159.2\end{array}$

(2807)

$48.1 \quad 0.38 \quad 85.4$

(TOTAL)

Odonata

Argia tibialis

Plecoptera

$$
\text { Isoperla sp. }
$$

(GRAND TOTAL)

30

$30 \quad 0.46 \quad 103.9$

$\begin{array}{lll}77 & 0.58 & 129.4\end{array}$

(9383)

(1757.8) 
TABLE 3. Annual Mean Density and Biomass of Insects from Snively Springs ( $S E=$ standard error, $C V=$ coefficient of variation)

\begin{tabular}{|c|c|c|c|c|c|c|}
\hline Taxa & $\begin{array}{l}\text { Density } \\
\left(\text { no. } / m^{2}\right)\end{array}$ & $S E / \bar{X}$ & $\mathrm{CV}$ & $\begin{array}{l}\text { Biomass } \\
\left(\mathrm{mg} / \mathrm{m}^{2}\right)\end{array}$ & $\mathrm{SE} / \overline{\mathrm{X}}$ & CV \\
\hline \multicolumn{7}{|l|}{ Diptera } \\
\hline Simulium sp. & 276 & 0.70 & 121.3 & 34.3 & 0.82 & 142.6 \\
\hline Chaetocladius sp. & 92 & 0.63 & 108.3 & 2.7 & 0.69 & 120.2 \\
\hline Chironomus sp. & 412 & 0.54 & 93.2 & 17.1 & 0.58 & 99.8 \\
\hline Heleniella sp. & 381 & 0.40 & 69.2 & 9.2 & 0.37 & 64.7 \\
\hline Polypeditum sp. & 123. & 0.56 & 96.2 & 3.2 & 0.52 & 89.1 \\
\hline Thienemannimyia sp. & 18 & 0.42 & 72.3 & 1.1 & 0.33 & 57.3 \\
\hline Dixidae & 21 & 0.55 & 95.9 & 1.3 & 0.65 & 111.5 \\
\hline Tabanidae & 52 & 0.47 & 81.5 & 10.5 & 0.50 & 86.4 \\
\hline Tipulidae & 25 & 0.60 & 103.8 & 219.2 & 0.50 & 87.4 \\
\hline Empididae & 4 & 0.15 & 26.6 & 0.6 & 0.12 & 32.1 \\
\hline (TOTAL) & (1404) & & & $(299.2)$ & & \\
\hline \multicolumn{7}{|l|}{ Trichoptera } \\
\hline Cheumatopsyche sp. & 433 & 0.41 & 83.0 & 200.9 & 0.51 & 86.9 \\
\hline \multicolumn{7}{|l|}{ Ephemeroptera } \\
\hline Baet is sp. & 1388 & 0.62 & 104.7 & 185.4 & 0.55 & 96.3 \\
\hline$\frac{\text { Para leptophlebia }}{\text { (TOTAL) }}$ & $\begin{array}{c}54 \\
(1442)\end{array}$ & 0.27 & 47.5 & $\begin{array}{c}15.5 \\
(200.9)\end{array}$ & 0.28 & 48.2 \\
\hline \multicolumn{7}{|l|}{ Odonata } \\
\hline Argia tibialis & 22 & 0.61 & 106.6 & 27.8 & 0.68 & 118.6 \\
\hline (GRANO TOTAL) & (3301) & & & $(728.8)$ & & \\
\hline
\end{tabular}

the total insect numbers and $90 \%$ of the total biomass. Annual mean density and biomass of grazer-scrapers was $4637 / \mathrm{m}^{2}$ and $670.7 \mathrm{mg} \mathrm{DW} / \mathrm{m}^{2}$, respectively. Annual mean density and biomass of collectors was $4494 / \mathrm{m}^{2}$ and $917.9 \mathrm{mg} \mathrm{DW} / \mathrm{m}^{2}$, respectively (Table 8 ).

Snively Springs

Collectors were by far the most abundant functional group in Snively Springs, accounting for $93 \%$ of the total insect numbers and 
TABLE 4. Annual Mean Density and Biomass of Insects from Rattlesnake Springs ( $S E=$ standard error, $C V=$ coefficient of variation $)$

\begin{tabular}{|c|c|c|c|c|c|c|}
\hline Taxa & $\begin{array}{l}\text { Density } \\
\left(\mathrm{no} . / \pi^{2}\right)\end{array}$ & SE $/ \bar{X}$ & $\mathrm{CV}$ & $\begin{array}{l}\text { Biomass } \\
\left(\mathrm{mg} / \mathrm{m}^{2}\right) \\
\end{array}$ & SE / $\bar{X}$ & $\mathrm{CV}$ \\
\hline \multicolumn{7}{|l|}{ Diptera } \\
\hline Simulium sp. & 1777 & 0.73 & 125.8 & 212.3 & 0.73 & 127.5 \\
\hline Chironomus sp. & 192 & 0.50 & 87.3 & 7.0 & 0.58 & 100.8 \\
\hline Thienemannimy ia sp. & 114 & 0.55 & 94.9 & 3.3 & 0.55 & 95.2 \\
\hline Chaetocladius sp. & & 0.73 & 126.4 & 0.4 & 0.56 & 97.7 \\
\hline Heleniella sp. & 352 & 0.51 & 89.0 & 5.4 & 0.51 & 88.4 \\
\hline Polypedilum sp. & 13 & 0.62 & 108.2 & 0.6 & 0.46 & 78.9 \\
\hline Misc. Chironomidae & 18 & 0.29 & 50.1 & 0.8 & 0.38 & 66.3 \\
\hline Dixidae & 2 & 0.28 & 64.7 & 0.1 & 0.29 & 50.0 \\
\hline Tabanidae & 34 & 0.51 & 85.6 & 15.9 & 0.64 & 111.0 \\
\hline Tipulidae & 3 & 0.21 & 35.9 & 2.0 & 0.26 & 44.3 \\
\hline Empididae & 8 & 0.39 & 68.3 & 0.4 & 0.23 & 39.8 \\
\hline (TOTAL) & $(2572)$ & & & $(248.2)$ & & \\
\hline \multicolumn{7}{|l|}{ Trichoptera } \\
\hline Cheumatopsyche sp. & 140 & 0.69 & 118.9 & 48.6 & 0.78 & 134.5 \\
\hline Limnephilus sp. & 52 & 0.45 & 76.9 & 22.0 & 0.38 & 66.3 \\
\hline Parapsyche sp. & 10 & 0.24 & 41.7 & $\begin{array}{l}26.8 \\
108 \quad 31\end{array}$ & 0.25 & 43.4 \\
\hline & & & & & & \\
\hline \multicolumn{7}{|l|}{ Coleoptera } \\
\hline Hydaticus sp. & 4 & 0.50 & 87.4 & 1.2 & 0.35 & 60.1 \\
\hline Hydrophilidae & 1 & 0.27 & 47.6 & 0.3 & 0.25 & 43.1 \\
\hline (TOTAL) & (5) & & & $(1.5)$ & & \\
\hline \multicolumn{7}{|l|}{ Ephemeroptera } \\
\hline Baetis sp. & 1336 & 0.61 & 107.2 & 47.3 & 0.58 & 104.0 \\
\hline Tricorythodes sp. & 1 & 0.05 & 8.3 & 0.3 & 0.07 & 12.2 \\
\hline (TOTAL) & $(1337)$ & & & $(47.6)$ & & \\
\hline \multicolumn{7}{|l|}{ Odonata } \\
\hline Argia tibialis & 67 & 0.72 & 124.1 & 74.3 & 0.78 & 134.9 \\
\hline (GRAND TOTAL) & $(4183)$ & & & $(469.9)$ & & \\
\hline
\end{tabular}


TABLE 5. Results of Qualitative Gut Content Analysis and Subsequent Functional Group and Trophic Level Classification for Insects from Douglas Creek ( $N=$ number of guts examined)

\begin{tabular}{|c|c|c|c|c|}
\hline Taxa & $\underline{N}$ & $\begin{array}{c}\text { Gut } \\
\text { Content }\end{array}$ & $\begin{array}{l}\text { Functional } \\
\text { Group } \\
\end{array}$ & $\begin{array}{l}\text { Trophic } \\
\text { Level }\end{array}$ \\
\hline \multicolumn{5}{|l|}{ Diptera } \\
\hline Simulium sp. & 14 & detritus & $\begin{array}{l}\text { coll-gath } \\
\text { shredder }\end{array}$ & detritivore \\
\hline Chiromonus sp. & 21 & $\begin{array}{l}\text { detritus/ } \\
\text { some algae }\end{array}$ & coll-gath & detritivore \\
\hline Parametriocnemus sp. & 14 & $\begin{array}{l}\text { detritus/ } \\
\text { some algae }\end{array}$ & coll-gath & detritivore \\
\hline Thienemannimyia sp. (a) & & & predator & carnivore \\
\hline $\begin{array}{l}\text { Chaetocladius s} \\
\text { Polypedilum sp. }\end{array}$ & 10 & detritus & $\begin{array}{l}\text { coll-gath } \\
\text { shredder }\end{array}$ & $\begin{array}{l}\text { detritivore } \\
\text { herbivore }\end{array}$ \\
\hline $\begin{array}{l}\text { Heleniella sp. } \\
\text { Phaenospeçtra sp. (a) }\end{array}$ & 10 & detritus & $\begin{array}{l}\text { coll-gath } \\
\text { scraper }\end{array}$ & $\begin{array}{l}\text { detritivore } \\
\text { herbivore }\end{array}$ \\
\hline $\begin{array}{l}\text { Tabanidae(d) } \\
\text { Tipulidae(a) } \\
\text { Empididae(a) }\end{array}$ & & & $\begin{array}{l}\text { predator } \\
\text { shredder } \\
\text { predator }\end{array}$ & $\begin{array}{l}\text { carnivore } \\
\text { detritivore } \\
\text { carnivore }\end{array}$ \\
\hline \multicolumn{5}{|l|}{ Trichoptera } \\
\hline Leucotrichia pictipes & 17 & $\begin{array}{l}\text { algae/some } \\
\text { detritus }\end{array}$ & scraper & herbivare \\
\hline Hydropsyche sp. & 45 & detritus & $\operatorname{coll-filt}$ & detritivore \\
\hline Cheumatopsyche sp. & 16 & detritus & coll-filt & detritivore \\
\hline \multicolumn{5}{|l|}{ Coleoptera } \\
\hline Optioservus sp. & 50 & $\begin{array}{l}\text { algae/some } \\
\text { detritus }\end{array}$ & scraper & herbivore \\
\hline \multicolumn{5}{|l|}{ Ephemeroptera } \\
\hline Leucrocuta sp. & 44 & $\begin{array}{l}\text { algae/some } \\
\text { detritus }\end{array}$ & scraper & nerbivore \\
\hline Baetis sp. & 51 & $\begin{array}{l}\text { detritus/ } \\
\text { some algae }\end{array}$ & coll-gath & detritivore \\
\hline Paraleptophlebia sp. & 44 & $\begin{array}{l}\text { detritus/ } \\
\text { some algae }\end{array}$ & coll-gath & detritivore \\
\hline Tricorythodes sp. & 7 & $\begin{array}{l}\text { detritus/ } \\
\text { some algae }\end{array}$ & coll-gath & detritivore \\
\hline $\begin{array}{l}\text { Odonata } \\
\text { Argia tibialis (a) }\end{array}$ & & & predator & carnivore \\
\hline \multicolumn{5}{|l|}{ Plecoptera } \\
\hline Isaperla sp. & 26 & $\begin{array}{l}\text { animal- } \\
\text { tissue }\end{array}$ & predator & carnivore \\
\hline
\end{tabular}

(a) Classifications based upon literature only (Merritt and Cumtrins 1984). 
TABLE 6. Results of Qualitative Gut Content Analysis and Subsequent Functional Group and Trophic Level Classification of Insects from Snively Springs ( $N=$ number of guts analyzed)

\begin{tabular}{|c|c|c|c|c|}
\hline Taxa & $N$ & $\begin{array}{c}\text { Gut } \\
\text { Content } \\
\end{array}$ & $\begin{array}{c}\text { Functional } \\
\text { Group } \\
\end{array}$ & $\begin{array}{c}\text { Trophic } \\
\text { Level }\end{array}$ \\
\hline \multicolumn{5}{|l|}{ Diptera } \\
\hline Simulium sp. & 43 & detritus & coll-filt & detritivore \\
\hline Chironomus sp. & 14 & detritus/ & coll-gath & detritivore \\
\hline Heleniella $s p$. & 14 & $\begin{array}{l}\text { detritus/ } \\
\text { some algae }\end{array}$ & coll-gath & detritivore \\
\hline Polypedilum sp.(a) & & & shredder & herbivore \\
\hline Thienemannimyia sp. (a) & & & predator & carnivore \\
\hline $\begin{array}{l}\text { Dixidae(d) } \\
\text { Tabanidae (a) } \\
\text { Tipulidae (a) } \\
\text { Empididae (a) }\end{array}$ & & & $\begin{array}{l}\text { coll-gath } \\
\text { predator } \\
\text { shredder } \\
\text { predator }\end{array}$ & $\begin{array}{l}\text { detritivore } \\
\text { carnivore } \\
\text { detritivore } \\
\text { carnivore }\end{array}$ \\
\hline
\end{tabular}

Trichoptera

Cheumatopsyche sp. 41 detritus coll-filt detritivore

Ephemeroptera

Baetis sp. 36 detritus coll-gath detritivore

Paraleptophlebia sp. 10 detritus coll-gath detritivore

Odonata

Argiatibialis $\quad 11$ animal- predator carnivore

tissue

(a) Classifications based upon literature only (Merritt and Cummins 1984).

$64 \%$ of the total biomass. Annual mean density was $3057 / \mathrm{m}^{2}$ and the annual mean biomass was $466.4 \mathrm{mg} \mathrm{DW} / \mathrm{m}^{2}$. No grazer-scrapers were found in Snively Springs (Table 9).

Rattlesnake Springs

As in Snively Springs, collectors were the most abundant functiona? group in Rattlesnake Springs, accounting for $93 \%$ of the total insect 
TABLE 7. Results of Qualitative Gut Content Analysis and Subsequent Functional Group and Trophic Level Classification of Insects from Rattlesnake Springs ( $N=$ number of guts analyzed)



(a) Classifications based upon literature only (Merritt and Cummins 1984). 
TABLE 8. Annual Mean Density and Biomass of Insect Functional Groups in Douglas Creek

\begin{tabular}{|c|c|c|c|c|}
\hline $\begin{array}{c}\text { Functional } \\
\text { Group }\end{array}$ & $\begin{array}{l}\text { Density } \\
\left(\text { no. } / \pi^{2}\right) \\
\end{array}$ & $\begin{array}{c}\text { Composition } \\
(\%)\end{array}$ & $\begin{array}{l}\text { Biomass } \\
\left(\mathrm{mg} / \mathrm{m}^{2}\right) \\
\end{array}$ & $\begin{array}{c}\text { Composition } \\
(\%)\end{array}$ \\
\hline Grazer-scraper & 4637 & 49.4 & 670.7 & 38.2 \\
\hline Collector (TOTAL) & (4494) & $(47.9)$ & $(917.9)$ & $(52.2)$ \\
\hline Gatherer & 3852 & 41.1 & 389.1 & 22.1 \\
\hline Filterer & 642 & 6.8 & 528.8 & 30.1 \\
\hline Shredder & 82 & 0.9 & 86.1 & 4.9 \\
\hline Predator & 170 & 1.8 & 83.1 & 4.7 \\
\hline (GRAND TOTAL) & $(9383)$ & $(100.0)$ & $(1757.8)$ & $(100.0)$ \\
\hline
\end{tabular}

TABLE 9. Annual Mean Density and Biomass of Insect Functional Groups in Snively Springs

\begin{tabular}{|c|c|c|c|c|}
\hline $\begin{array}{c}\text { Functional } \\
\text { Group }\end{array}$ & $\begin{array}{l}\text { Density } \\
\left(\mathrm{no}_{0} / \mathrm{m}^{2}\right)\end{array}$ & $\begin{array}{c}\text { Composition } \\
(\%)\end{array}$ & $\begin{array}{l}\text { Biomass } \\
\left(\mathrm{mg} / \mathrm{m}^{2}\right) \\
\end{array}$ & $\begin{array}{c}\text { Composition } \\
(\%)\end{array}$ \\
\hline Collector (TOTAL) & $(3057)$ & $(92.6)$ & $(466.4)$ & $(64.0)$ \\
\hline Gatherer & 2348 & 71.1 & 231.2 & 31.7 \\
\hline Filterer & 709 & 21.5 & 235.2 & 32.3 \\
\hline Shredder & 148 & 4.5 & 222.4 & 30.5 \\
\hline Predator & 96 & 2.9 & 40.0 & 5.5 \\
\hline (GRAND TOTAL) & (3301) & $(100.0)$ & $(728.8)$ & $(100.0)$ \\
\hline
\end{tabular}

numbers and $74 \%$ of the total biomas5. Annual mean density and biomass of collectors was $3887 / \mathrm{m}^{2}$ and $349.0 \mathrm{mg} \mathrm{DW} / \mathrm{m}^{2}$, respectively. Grazerscrapers were absent from Rattlesnake Springs (Table 10).

TROPHIC LEVEL DENSITY AND BIOMASS

Trophic level elassifications for insects from Douglas Creek, Snively Springs, and Rattlesnake Springs are shown in Tables 5, 6, and 7 , respectively.

Douglas Creek

Herbivores $(50 \%)$ and detritivores (48\%) were the most abundant trophic levels in Douglas Creek. These trophic levels accounted for 
TABLE 10. Annua] Mean Density and Biomass of Insect Functional Groups in Rattlesnake Springs

\begin{tabular}{|c|c|c|c|c|}
\hline $\begin{array}{c}\text { Functional } \\
\text { Group }\end{array}$ & $\begin{array}{l}\text { Density } \\
\left(\text { no. } / \mathrm{m}^{2}\right) \\
\end{array}$ & $\begin{array}{c}\text { Composition } \\
(\%)\end{array}$ & $\begin{array}{l}\text { Biomass } \\
\left(\mathrm{mg} / \mathrm{m}^{2}\right) \\
\end{array}$ & $\begin{array}{c}\text { Composition } \\
(\%)\end{array}$ \\
\hline Collector (TOTAL) & $(3887)$ & $(92.9)$ & $(349.0)$ & $(74.3)$ \\
\hline Gatherer & 1960 & 46.9 & 61.3 & 13.1 \\
\hline Filterer & 1927 & 46.1 & 287.7 & 61.2 \\
\hline Shredder & 68 & 1.6 & 25.5 & 5.4 \\
\hline Predator & 228 & 5.5 & 95.4 & 20.3 \\
\hline (GRAND TOTAL) & (4183) & $(100.0)$ & $(469.9)$ & $(100.0)$ \\
\hline
\end{tabular}

$98 \%$ of the total insect numbers and $95 \%$ of the total biomass. Annual mean density and biomass of herbivores was $4670 / \mathrm{m}^{2}$ and $672.9 \mathrm{mg} \mathrm{DW} / \mathrm{m}^{2}$, respectively. The annual mean density and biomass of detritivores was $4543 / \mathrm{m}^{2}$ and $1004.4 \mathrm{mg} \mathrm{DW} / \mathrm{m}^{2}$, respectively (Table 11 ).

Snively Springs

Detritivores were by far the most abundant trophic level in Snively Springs, accounting for $93 \%$ of the total insect numbers and $94 \%$ of the total biomass. Annual mean density was $3082 / \mathrm{m}^{2}$ and the annual mean biomass was $685.6 \mathrm{mg} \mathrm{DW} / \mathrm{m}^{2}$ (Table 12 ).

\section{Rattlesnake Springs}

Detritivores were the most abundant trophic level in Rattlesnake Springs. Detritivores comprised $94 \%$ of the total insect numbers and $80 \%$ of the total biomass. Annual mean density was $3942 / \mathrm{m}^{2}$ and the annual mean biomass was $373.9 \mathrm{mg} \mathrm{DW} / \mathrm{m}^{2}$ (Table 13 ).

TABLE 11. Annual Mean Density and Biomass of Insect Trophic Levels in Douglas Creek

\begin{tabular}{|c|c|c|c|c|}
\hline $\begin{array}{c}\text { Trophic } \\
\text { Level }\end{array}$ & $\begin{array}{l}\text { Density } \\
\left(\text { no. } / \mathrm{m}^{2}\right)\end{array}$ & $\begin{array}{c}\text { Composition } \\
(\%)\end{array}$ & $\begin{array}{l}\text { Biomass } \\
\left(\mathrm{mg} / \mathrm{m}^{2}\right) \\
\end{array}$ & $\begin{array}{c}\text { Composition } \\
(\%)\end{array}$ \\
\hline Herbivore & 4670 & 49.8 & 672.9 & 38.3 \\
\hline Detritivore & 4543 & 48.4 & 1004.4 & 57.1 \\
\hline $\begin{array}{l}\text { Carnivore } \\
\text { (GRAND TOTAL) }\end{array}$ & $\frac{170}{(9383)}$ & $\frac{1.8}{(100.0)}$ & $\frac{80.5}{(1757.8)}$ & $\frac{4.6}{(100.0)}$ \\
\hline
\end{tabular}


TABLE 12. Annual Mean Density and Biomass of Insect Trophic Levels in Snively Springs

\begin{tabular}{|c|c|c|c|c|}
\hline $\begin{array}{c}\text { Trophic } \\
\text { Level }\end{array}$ & $\begin{array}{l}\text { Density } \\
\left(\text { no. } / m^{2}\right) \\
\end{array}$ & $\begin{array}{c}\text { Composition } \\
(\%)\end{array}$ & $\begin{array}{l}\text { Biomass } \\
\left(\mathrm{mg} / \mathrm{m}^{2}\right) \\
\end{array}$ & $\begin{array}{c}\text { Composition } \\
(\%)\end{array}$ \\
\hline Herbivore & 123 & 3.7 & 3.2 & 0.4 \\
\hline Detritivore & 3082 & 93.4 & 685.6 & 94.1 \\
\hline Carnivore & 96 & 2.9 & 40.0 & 5.5 \\
\hline (GRAND TOTAL) & (3301) & $(100.0)$ & $(728.8)$ & $(100.0)$ \\
\hline
\end{tabular}

TABLE 13. Annual Mean Density and Biomass of Insect Trophic Levels in Rattlesnake Springs

\begin{tabular}{|c|c|c|c|c|}
\hline $\begin{array}{c}\text { Trophic } \\
\text { Level }\end{array}$ & $\begin{array}{l}\text { Density } \\
(\text { no./min }) \\
\end{array}$ & $\begin{array}{c}\text { Composition } \\
(\%) \\
\end{array}$ & $\begin{array}{l}\text { Biomass } \\
\left(\mathrm{mg} / \mathrm{m}^{2}\right) \\
\end{array}$ & $\begin{array}{c}\text { Composition } \\
(\%)\end{array}$ \\
\hline Herbivore & 13 & 0.3 & 0.6 & 0.1 \\
\hline Detritivore & 3942 & 94.2 & 373.9 & 79.6 \\
\hline Carnivore & 228 & 5.5 & 95.4 & 20.3 \\
\hline (GRAND TOTAL) & $(4183)$ & $(100.0)$ & $(469.9)$ & $(100.0)$ \\
\hline
\end{tabular}

INSECT PRODUCTION

Douglas Creek

Diptera--Previous studies have addressed the difficulties in obtaining accurate field estimates of blackfly larvae (Simuliidae) and midge larvae (Chironomidae) CPIs, and thus production estimates (Benke et a). 1984, Behmer and Hawkins 1986). Their small size, rapid turnover rate, high density, and diversity make accurate species-specific CPI estimates difficult. These same characteristics, however, make midges and blackflies very important to a stream community. In many streams these insects contribute a large percentage of the total community production because of their rapid development and high turnover rates.

Simulium sp. (blackflies) from Douglas Creek were not present in sufficient numbers to calculate a size-frequency (SF) production estimate. A P/B ratio of 54.0 was used to estimate production. This $P / B$ ratio was calculated by using the $S F$ method to average the $P / B$ 
ratios obtained for Simulium sp. in Snively Springs and Rattlesnake Springs. Blackfly production in Douglas Creek was $1638.2 \mathrm{mg} \mathrm{DW} / \mathrm{m}^{2} / \mathrm{yr}$ (Table 14).

Accurate CPI estimates for Chironomidae (midges) could not be obtained from field observations or SF distributions. Benke et al. (1984) provide an extensive review of literature concerning midge development times. Using these data and Mackey's (1977) laboratory growth studies, I feel that reasonable CPI estimates were derived.

Mackey (1977) reported larval development times of 21 days for Chironomus sp., 13 days for Polypedilum convictim, and 36 days for Phaenospectra flavipes at $15^{\circ} \mathrm{C}$. To compensate for slightly lower average temperatures $\left(13^{\circ} \mathrm{C}\right)$ in Douglas Creek, and environmental stress, I estimated CPIs of 25 days for Chironomus, 20 days for Polypedilum, and 40 days for Phaenospectra. For the remaining midge species I assumed a CPI of 25 days. Production estimates ranged from $67.5 \mathrm{mg} \mathrm{DW} / \mathrm{m}^{2} / \mathrm{yr}$ by Brilla flavifrons to $4922.8 \mathrm{mg} \mathrm{DW} / \mathrm{m}^{2} / \mathrm{yr}$ by Chironomus. Annual $\mathrm{P} / \mathrm{B}$ ratios ranged from 45.0 by Phaenospectra to 121.7 by Chaetocladius. These $P / B$ ratios seem high but are comparable to those reported in other studies when short CPIs were utilized (Benke et al. 1984, Jackson and Fisher 1986).

Tabanidae and Tipulidae were assumed to be univoltine with a development time of 1 year. This is consistent with Gray's (1981) estimate of a l-year development time for Tabanus dorsifer (Tabanidae) in Sycamore Creek, Arizona. Empididae grew to a maximum size that was similar to many of the midges, therefore a CPI of 25 days was assumed. Table 14 shows production data for all dipterans in Douglas Creek.

Trichoptera--Leucotrichia pictipes (microcaddisfly) was univoltine, and as SF distributions and field observations indicated the larvae overwintered as a late instar and emerged as adults in the spring. This observation is supported by McAuliffe's (1982) studies on L. pictipes in Owl Creek, Montana. Production and the annual P/B ratio of Leucotrichia sp. in Douglas Creek were $32.0 \mathrm{mg} \mathrm{DW} / \mathrm{m}^{2} / \mathrm{yr}$ and 4.2 , respectively. 
TABLE 14. Annual Production of Insects from Douglas Creek, July 1985 to June 1986

\begin{tabular}{|c|c|c|c|c|}
\hline Taxa & $365 / \mathrm{CPI}$ & $\begin{array}{l}\text { Calculation } \\
\text { Method } a, b) \\
\end{array}$ & $\begin{array}{l}\text { Production } \\
\left(\mathrm{mg} / \mathrm{m}^{2} / \mathrm{yr}\right)\end{array}$ & $\begin{array}{c}\text { Annua } \\
P / B\end{array}$ \\
\hline $\begin{array}{l}\text { Diptera } \\
\text { Simulium sp. } \\
\text { Brilla flavifrons } \\
\text { Chironomus sp. } \\
\text { Parametriocnemus } s p \text {. } \\
\text { Thienemannimyia } s p \text {. } \\
\text { Chaetocladius } s p . \\
\text { Polypedilum } s p . \\
\text { heleniella sp. } \\
\text { Phaenospectra } s p . \\
\text { Tabanidae } \\
\text { Tipulidae } \\
\text { Empididae } \\
\text { (ToTAL) }\end{array}$ & $\begin{array}{r}12 \\
15 \\
15 \\
15 \\
15 \\
15 \\
18 \\
15 \\
9 \\
1 \\
1 \\
15\end{array}$ & $\begin{array}{l}\text { PB } \\
P B \\
P B \\
\text { SF } \\
P B \\
\text { SF } \\
\text { SF } \\
\text { SF } \\
\text { PB } \\
P B \\
\text { PB } \\
\text { PB }\end{array}$ & $\begin{array}{r}1638.2 \\
67.5 \\
4922.8 \\
874.5 \\
75.2 \\
426.0 \\
160.9 \\
423.0 \\
220.5 \\
130.0 \\
410.5 \\
7.5 \\
(9365.6)\end{array}$ & $\begin{array}{c}54.0(\mathrm{c}) \\
75.0(\mathrm{~d}) \\
81.1(\mathrm{c}) \\
84.1 \\
83.6(\mathrm{c}) \\
121.7 \\
73.1 \\
94.0 \\
45.0(\mathrm{c}) \\
5.0(\mathrm{c}) \\
5.0(\mathrm{c}) \\
75.0(\mathrm{c})\end{array}$ \\
\hline $\begin{array}{l}\text { Trichoptera } \\
\text { Leucotrichia pictipes } \\
\frac{\text { Hydropsyche sp. }}{\text { Cheumatopsyche sp. }}\end{array}$ & $\begin{array}{l}1 \\
1 \\
2\end{array}$ & $\begin{array}{l}\text { SF } \\
\text { SF } \\
\text { SF }\end{array}$ & $\begin{array}{r}32.0 \\
1700.0 \\
817.5 \\
(2549.5)\end{array}$ & $\begin{array}{l}4.2 \\
4.1 \\
9.7\end{array}$ \\
\hline $\begin{array}{l}\text { Coleoptera } \\
\text { Optioservus sp. }\end{array}$ & 1 & SF & 2162.7 & 3.6 \\
\hline $\begin{array}{l}\text { Ephemeroptera } \\
\text { Leucrocuta sp. } \\
\frac{\text { Baetis sp. }}{\text { Paraleptophlebia } s p \text {. }} \frac{\text { Tricorythodes } s p .}{\text { (TOTAL) }}\end{array}$ & $\begin{array}{l}1 \\
6 \\
1 \\
9\end{array}$ & $\begin{array}{l}\text { SF } \\
\text { SF } \\
\text { SF } \\
\text { PB }\end{array}$ & $\begin{array}{r}237.8 \\
8316.5 \\
249.4 \\
76.5 \\
(8880.2)\end{array}$ & $\begin{array}{r}4.6 \\
31.5 \\
5.2 \\
45.0(\mathrm{c})\end{array}$ \\
\hline $\begin{array}{l}\text { Odonata } \\
\text { Argia tibialis }\end{array}$ & 1 & PB & 44.3 & $5.0(c)$ \\
\hline $\begin{array}{l}\text { Plecoptera } \\
\text { Isoperla sp. }\end{array}$ & 1 & SF & 182.8 & 4.3 \\
\hline (GRANO TOTAL) & & & $(23185.1)$ & \\
\hline
\end{tabular}

(a) $\mathrm{PB}=$ production calculated by an assumed $\mathrm{P} / \mathrm{B}$ ratio.

(b) $\mathrm{SF}=$ production calculated by the size-frequency method.

(c) Assumed cohort $P / B$ of 5 .

(d) Assumed annual $P / B$ is the same as derived by $S F$ for this species in one of the other study streams. 
Field observations and SF distributions of Hydropsyche sp. and Cheumatopsyche $s p$. indicated CPIs of 1 year and 6 months, respectively. Production and the annual $P / B$ ratio of Hydropsyche $s p$. Were $1700.0 \mathrm{mg} \mathrm{DW} / \mathrm{m}^{2} / \mathrm{yr}$ and 4.1 , respectively. Production of Cheumatopsyche $\mathrm{sp}$. was $817.5 \mathrm{mg} \mathrm{OW} / \mathrm{m}^{2} / \mathrm{yr}$ and the annual $\mathrm{P} / \mathrm{B}$ ratio was 9.7 . Total caddisfly production was $2549.5 \mathrm{mg} \mathrm{DW} / \mathrm{m}^{2} / \mathrm{yr}$ (Table 14).

Coleoptera-An accurate CPI estimate for Optioservus sp. (riffle beetles) was difficult to make because few data are available concerning their development times. Field data, though not clearcut, indicated a CPI of 1 year. Using this CPI estimate, production of riffle beetles was $2162.7 \mathrm{mg} \mathrm{DW} / \mathrm{m}^{2} / \mathrm{yr}$ and the annual $\mathrm{P} / \mathrm{B}$ ratio was 3.6 (Table 14 ).

Ephemeroptera--Mayflies typically exhibit widely varied larval development times (Clifford 1982). I assumed Leucrocuta sp. (Heptageniidae) to be univoltine with a CPI of 1 year. Clifford (1982) examined life-cycle data of 85 species of Heptagenitidae and found $>90 \%$ had at least one univoltine life cycle. Production of Leucrocuta sp. was $237.8 \mathrm{mg} D \mathrm{~W} / \mathrm{m}^{2} / \mathrm{yr}$ and the annual $P / B$ ratio was 4.6 .

Field data for Baetis sp. from Douglas Creek provided little clarification of their CPI. Based upon field observations of Baetis sp. from the other study streams, and a growth study in Rattlesnake Springs (Gaines, unpublished data), I estimated a CPI of 60 days. Temperature regimes were similar between study streams, making this estimation reasonable. Production of Baetis sp., $8316.5 \mathrm{mg} \mathrm{DW} / \mathrm{m}^{2} / \mathrm{yr}$, was the highest of all insects from Douglas Creek. The annual $P / B$ ratio was 31.5 (Table 14).

Paraleptophlebia $s p$. are generally univoltine, having either a summer or winter cycle (Clifford 1982). In Douglas Creek, however, seasonal cycles could not be distinguished. Since all Paraleptophlebia species have at least one univoltine cycle (Clifford 1982) and were present in Douglas Creek throughout the study year, I assumed a CPI of 1 year. Production was $249.4 \mathrm{mg} \mathrm{DW} / \mathrm{m}^{2} / \mathrm{yr}$ and the annual $\mathrm{P} / \mathrm{B}$ ratio was 5.2 (Table 14). 
Because of low numbers of Tricorythodes sp., field data provided little indication of their CPI. McCullough et al. (1979) reported a 34-day larval development time for Tricorythodes minutus grown in the field at $18^{\circ} \mathrm{C}$. I estimated a CPI of 40 days for Tricorythodes $\mathrm{SP}$. because of lower stream temperatures in Douglas Creek. A cohort $P / B$ ratio of 5 was assumed to estimate production of $76.5 \mathrm{mg} \mathrm{DW} / \mathrm{m}^{2} / \mathrm{yr}$ (Table 14).

Odonata-Argia tibialis (damselflies) were univoltine and field data indicated a CPI of 1 year. I assumed a cohort $P / 8$ ratio of 5.0 to estimate production of $44.3 \mathrm{mg} \mathrm{DW} / \mathrm{m}^{2} / \mathrm{yr}$ (Table 14).

Plecoptera--A CPI estimate for Isoperla $5 p$. (stoneflies) could not be made from field data. I assumed a CPI of 1 year because stoneflies grew to a maximum size that was similar to damselflies. Production was $182.8 \mathrm{mg} \mathrm{DW} / \mathrm{m}^{2} / \mathrm{yr}$ and the annual $\mathrm{P} / \mathrm{B}$ ratio was 4.3 (Table 14 ). Snively Springs

Diptera--Field data and observations indicated a larval development time (CPI) of 30 days for Simulium sp. (blackflies) in Snively Springs. Becker (1973) reported a larval development time of 13 days for S. vittatum grown in the laboratory at $17^{\circ} \mathrm{C}$. A 30 -day CPI was a reasonable estimate when lower stream temperatures and environmental stress are considered. On this basis, production was $1878.7 \mathrm{mg} \mathrm{DW} / \mathrm{m}^{2} / \mathrm{yr}$ and the annual $P / B$ ratio was 54.8 (Table 15 ).

The larval development times (CPIs) of Chironomidae (midges) in Snively Springs were estimated as they were in Douglas Creek. I assumed CPIs of 20 days for Polypedilum sp. and 25 days for all other midges. Production estimates ranged from $92.0 \mathrm{mg} \mathrm{DW} / \mathrm{m}^{2} / \mathrm{yr}$ by Thienemannimyia $\mathrm{sp}$. to $1386.0 \mathrm{mg} \mathrm{DW} / \mathrm{m}^{2} / \mathrm{yr}$ by Chironomus $\mathrm{sp}$. The $\mathrm{P} / \mathrm{B}$ ratios ranged from 60.3 by Heleniella sp. to 83.6 by Thienemannimyia sp.

I assumed Tabanidae and Tipulidae to be univoltine with a CPI of 1 year (Gray 1981). Dixidae and Empididae reached maximum sizes that were very similar to many of the midges, and I assumed a CPI of 25 days. Table 15 shows the production data of all dipterans in Snively Springs. 
TABLE 15. Annual Production of Insects from Snively Springs, July 1985 to June 1986

\begin{tabular}{|c|c|c|c|c|}
\hline Taxa & $365 / \mathrm{CPI}$ & $\begin{array}{l}\text { Calculation } \\
\text { Method }(a, b) \\
\end{array}$ & $\begin{array}{l}\text { Production } \\
\left(\mathrm{mg} / \mathrm{m}^{2} / \mathrm{yr}\right) \\
\end{array}$ & $\begin{array}{c}\text { Annual } \\
P / B\end{array}$ \\
\hline \multicolumn{5}{|l|}{ Diptera } \\
\hline Simulium sp. & 12 & SF & 1878.7 & 54.8 \\
\hline Chaetocladius sp. & 15 & SF & 210.0 & 77.8 \\
\hline Chironomus sp. & 15 & SF & 1386.0 & 81.1 \\
\hline Heleniella sp. & 15 & SF & 550.0 & 60.3 \\
\hline Polypedilum sp. & 18 & SF & 219.6 & 68.6 \\
\hline Thienemannimyia sp. & 15 & PB & 92.0 & $83.6(c)$ \\
\hline$\overline{\text { Dixidae }}$ & 15 & PB & 97.5 & $75.0^{(d)}$ \\
\hline Tabanidae & 1 & $\mathrm{~PB}$ & 52.5 & $5.0(d)$ \\
\hline Tipulidae & 1 & PB & 1096.0 & $5.0^{(d)}$ \\
\hline $\begin{array}{l}\text { Empididae } \\
\text { (TOTAL) }\end{array}$ & 15 & PB & $\begin{array}{c}45.0 \\
(5627.3)\end{array}$ & $75.0(\mathrm{~d})$ \\
\hline \multicolumn{5}{|l|}{ Trichoptera } \\
\hline Cheumatopsyche sp. & 2 & SF & 1297.9 & 6.5 \\
\hline \multicolumn{5}{|l|}{ Ephemeroptera } \\
\hline Baetis SP. & 6 & SF & 7011.6 & 37.8 \\
\hline$\frac{\text { Paraleptophlebia sp. }}{\text { (TOTAL) }}$ & 1 & SF & $\begin{array}{c}67.0 \\
(7078.6)\end{array}$ & 4.3 \\
\hline \multicolumn{5}{|l|}{ Odonata } \\
\hline Argia tibialis & 1 & $\mathrm{~PB}$ & 139.1 & $5.0(d)$ \\
\hline (GRAND TOTAL) & & & $(14142.9)$ & \\
\hline
\end{tabular}

(a) $\mathrm{PB}=$ production calculated by an assumed $\mathrm{P} / \mathrm{B}$ ratio.

(b) $\mathrm{SF}=$ production calculated by the size-frequency method.

(c) Assumed cohort $P / B$ of 5 .

(d) Assumed annual $P / B$ is the same as derived by SF for this species in one of the other study streams.

Trichoptera--Field observations and SF data indicated a bivoltine life cycle and a CPI of 6 months for Cheumatopsyche sp., the only caddisfly in Snively Springs. Production was $1297.9 \mathrm{mg} \mathrm{DW} / \mathrm{m}^{2} / \mathrm{yr}$ and the annual $P / B$ ratio was 6.5 (Table 15 ). 
Ephemeroptera--Field observations and SF data indicated a CPI of 60 days for Baetis sp. in Snively Springs. Gray (1981) reported a larval development time of 20 days for Baetis quilleri in Sycamore Creek, Arizona. Due to lower stream temperatures, however, Baetis sp. developed more slowly in all of the streams in this study. Production by Baetis $\mathrm{sp}$. was $7011.6 \mathrm{mg} \mathrm{DW} / \mathrm{m}^{2} / \mathrm{yr}$ and the annual $\mathrm{P} / \mathrm{B}$ ratio was 37.8 (Table 15).

In Snively Springs, Paraleptophlebia sp. were present only during the summer. Thus, I used only data collected during the summer to calculate production. Production of Paraleptophlebia sp. was $67.0 \mathrm{mg}$ $\mathrm{DW} / \mathrm{m}^{2} / \mathrm{yr}$ and the annual $\mathrm{P} / \mathrm{B}$ ratio was 4.3 (Table 15 ).

Odonata--Argia tibialis were not present in sufficient numbers to make an SF production estimate. I assumed a cohort $P / B$ ratio of 5 and a

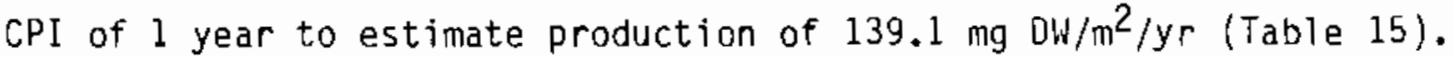
Rattlesnake Springs

Diptera--Several Simulium sp. Tarvae were isolated in growth chambers in Rattlesnake Springs to estimate larval development time. These data and field observations indicated a CPI of 30 days. Production by blackflies, $11174.8 \mathrm{mg} \mathrm{DW} / \mathrm{m}^{2} / \mathrm{yr}$, was the highest of all species in Rattlesnake Springs, and the annual P/B ratio was 52.6.

I estimated larval development times (CPIs) of Rattlesnake Springs Chironomidae as I did in the other study streams. CPIs of 20 days for Polypedilum Sp. and 25 days for all other midges were assumed. Production estimates ranged from $30.0 \mathrm{mg} 0 \mathrm{~W} / \mathrm{m}^{2} / \mathrm{yr}$ by Chaetocladius sp. to $489.0 \mathrm{mg} \mathrm{DW} / \mathrm{m}^{2} / \mathrm{yr}$ by Chironomus $\mathrm{sp}$. Annual $\mathrm{P} / \mathrm{B}$ ratios ranged from 68.6 by Polypedilum $s p$. to 83.6 by Thienemannimyia sp.

Tabanidae and Tipulidae were assumed to be univoltine with CPIs of 1 year (Gray 1981). Dixidae and Empididae grew to maximum sizes similar to many of the midges and CPIs of 25 days were assumed. Table 16 shows the production data of all dipterans from Rattlesnake Springs. 
Trichoptera--I isolated several Cheumatopsyche sp. larvae in growth chambers in Rattlesnake Springs to estimate larval development time. These data indicated a bivoltine life cycle and a CPI of 6 months. Production by caddisflies in Rattlesnake Springs was $486.0 \mathrm{mg} \mathrm{DW} / \mathrm{m}^{2} / \mathrm{yr}$ and the annual $P / B$ ratio was 10.0 (Table 16 ).

Because of low densities, field data gave no indication of the CPIs of Limnephilus sp. or Parapsyche $s p$. To estimate their production, I assumed a $C P I$ of 1 year and a cohort $P / B$ ratio of 5 . Production was $114.6 \mathrm{mg} \mathrm{DW} / \mathrm{m}^{2} / \mathrm{yr}$ by Limnephilus $\mathrm{sp}$. and $133.8 \mathrm{mg} \mathrm{DW} / \mathrm{m}^{2} / \mathrm{yr}$ by Parapsyche sp. (Table 16).

Coleoptera-Field data provided little indication of the CPIs of beetles (coleopterns) because of low numbers. To estimate production, $I$ assumed a CPI of 1 year and a cohort $P / B$ ratio of 5 . Production by Hydaticus $s p$. was $6.0 \mathrm{mg} \mathrm{DW} / \mathrm{m}^{2} / \mathrm{hr}$ (Table 16). Production by Hydrophilidae was $1.5 \mathrm{mg} \mathrm{DW} / \mathrm{m}^{2} / \mathrm{yr}$ (Table 16$)$.

Ephemeroptera--I isolated several Baetis sp. larvae in growth chambers in Rattlesnake Springs to estimate larval development time. These data and field observations indicated a CPI of 60 days. Production by Baetis $\mathrm{sp}$. was $2542.3 \mathrm{mg} \mathrm{DW} / \mathrm{m}^{2} / \mathrm{yr}$ and the annual $\mathrm{P} / \mathrm{B}$ ratio was 53.8 (Table 16).

Tricorythodes $s p$. were not present in sufficient numbers for an SF production estimate. I assumed a cohort $P / B$ ratio of 5 and a CPI of 40 days (McCullough et al. 1979) to calculate production of $13.5 \mathrm{mg}$ $\mathrm{DW} / \mathrm{m}^{2} / \mathrm{yr}$ (Table 16$)$.

Odonata--Field observations of Argia tibialis indicated a CPI of 1 year, and $I$ assumed a cohort $P / B$ ratio of 5 to calculate production. Production by damselflies in Rattlesnake Springs was $371.6 \mathrm{mg} \mathrm{DW} / \mathrm{m}^{2} / \mathrm{yr}$ (Table 16).

FUNCTIONAL GROUP PRODUCTION

Production by collectors was the highest of all functional groups in all study streams. Collector production was highest in Douglas Creek 
TABLE 16. Annual Production of Insects from Rattlesnake Springs, July 1985 to June 1986

\begin{tabular}{|c|c|c|c|c|}
\hline Taxa & $365 / \mathrm{CPI}$ & $\begin{array}{l}\text { Calculation } \\
\text { Method a,bs }\end{array}$ & $\begin{array}{l}\text { Production } \\
\left(\mathrm{mg} / \mathrm{m}^{2} / \mathrm{yr}\right) \\
\end{array}$ & $\begin{array}{c}\text { Annual } \\
P / B\end{array}$ \\
\hline $\begin{array}{l}\text { Diptera } \\
\text { Simulium sp. } \\
\text { Chíronomus sp. } \\
\text { Thienemannimyia sp. } \\
\text { Chaetocladius sp. } \\
\text { Heleniella sp. } \\
\text { Polypedilum sp. } \\
\text { Miscellaneous } \\
\text { Chironomidae }\end{array}$ & $\begin{array}{l}12 \\
15 \\
15 \\
15 \\
15 \\
18 \\
15\end{array}$ & $\begin{array}{l}S F \\
S F \\
S F \\
S F \\
S F \\
P B \\
P B\end{array}$ & $\begin{array}{r}11174.8 \\
489.0 \\
279.0 \\
30.0 \\
480.0 \\
41.2 \\
60.0\end{array}$ & $\begin{array}{l}52.6 \\
69.9 \\
B 3.6 \\
75.0(\mathrm{c}) \\
88.9 \\
68.6 \text { (d) } \\
75.0 \text { (c) }\end{array}$ \\
\hline $\begin{array}{l}\text { Dixidae } \\
\text { Tabanidae } \\
\text { Tipulidae } \\
\text { Empididae } \\
\text { (TOTAL) }\end{array}$ & $\begin{array}{r}15 \\
1 \\
1 \\
15\end{array}$ & $\begin{array}{l}\text { PB } \\
P B \\
P B \\
P B\end{array}$ & $\begin{array}{r}7.5 \\
79.5 \\
10.0 \\
30.0 \\
(12681.0)\end{array}$ & $\begin{array}{r}75.0(c) \\
5.0(c) \\
5.0(c) \\
75.0(c)\end{array}$ \\
\hline $\begin{array}{l}\text { Trichoptera } \\
\text { Cheumatopsyche } s p . \\
\frac{\text { Limnephilus } s p .}{\text { Parapsyche }} \text { Sp. } \\
\text { (TOTAL) }\end{array}$ & $\begin{array}{l}2 \\
1 \\
1\end{array}$ & $\begin{array}{l}\text { SF } \\
\text { PB } \\
\text { PB }\end{array}$ & $\begin{array}{l}486.0 \\
114.6 \\
133.8 \\
(734.4)\end{array}$ & $\begin{array}{r}10.0 \\
5.0(c) \\
5.0(c)\end{array}$ \\
\hline $\begin{array}{l}\text { Coleoptera } \\
\text { Hydaticus sp. } \\
\begin{array}{c}\text { Hydrophilidae } \\
\text { (TOTAL) }\end{array}\end{array}$ & $\begin{array}{l}1 \\
1\end{array}$ & $\begin{array}{l}P B \\
P B\end{array}$ & $\begin{array}{c}6.0 \\
1.5 \\
(7.5)\end{array}$ & $\begin{array}{l}5.0(c) \\
5.0(c)\end{array}$ \\
\hline $\begin{array}{l}\text { Ephemeroptera } \\
\text { Baetis sp. } \\
\frac{\text { Tricorythodes sp. }}{\text { (TOTAL) }}\end{array}$ & $\begin{array}{l}6 \\
9\end{array}$ & $\begin{array}{l}S F \\
P B\end{array}$ & $\begin{array}{c}2542.3 \\
13.5 \\
(2555.8)\end{array}$ & $\begin{array}{l}53.8 \\
45.0(c)\end{array}$ \\
\hline $\begin{array}{l}\text { Odonata } \\
\text { Argia tibialis }\end{array}$ & 1 & PB & 371.6 & $5.0(c)$ \\
\hline (GRAND TOTAL) & & & $(16350.3)$ & \\
\hline
\end{tabular}

\footnotetext{
(a) $\mathrm{PB}=$ production calculated by an as sumed $\mathrm{P} / \mathrm{B}$ ratio.

(b) $\mathrm{SF}=$ production calculated by the size-frequency method.

(c) Assumed cohort $P / B$ of 5 .

(d) Assumed annual $P / B$ is the same as derived by SF for this species in one of the other study streams.
} 
at $19444.4 \mathrm{mg} \mathrm{DW} / \mathrm{m}^{2} / \mathrm{yr}$, accounting for $84 \%$ of the total annual production. In Snively Springs, collector production was $12498.7 \mathrm{mg} \mathrm{DW} / \mathrm{m}^{2} / \mathrm{yr}$, comprising $88 \%$ of the total annual production. Production of collectors in Rattlesnake Springs was $15416.9 \mathrm{mg} \mathrm{DW} / \mathrm{m}^{2} / \mathrm{yr}$, accounting for $94 \%$ of the total annual production. Table 17 shows the annual production by functional groups in each study stream.

TROPHIC LEVEL PRODUCTION

Detritivore production was the highest of all trophic levels in each study stream. In Douglas Creek, detritivore production was $19922.4 \mathrm{mg} D W / \mathrm{m}^{2} / \mathrm{yr}$, accounting for $86 \%$ of the total annual production. In Snively Springs detritivore production was $13594.7 \mathrm{mg}$ $\mathrm{DW} / \mathrm{m}^{2} / \mathrm{yr}$, accounting for $96 \%$ of the total annual production. Detritivore production in Rattlesnake Springs was $15541.5 \mathrm{mg} \mathrm{DW} / \mathrm{m}^{2} / \mathrm{yr}$, accounting for $95 \%$ of the total annual production. Table 18 shows the annual production by trophic levels in each study stream.

TABLE 17. Annual Production of Insect Functional Groups in Douglas Creek, Snively Springs, and Rattlesnake Springs

\begin{tabular}{|c|c|c|c|c|c|c|}
\hline \multirow{2}{*}{$\begin{array}{l}\text { Functional } \\
\text { Group } \\
\text { Grazer-Scraper }\end{array}$} & \multicolumn{2}{|c|}{$\begin{array}{l}\text { Douglas Creek } \\
\left(\mathrm{mg} / \mathrm{m}^{2} / \mathrm{yr}\right)(\%)\end{array}$} & \multicolumn{2}{|c|}{$\begin{array}{l}\text { Snively Springs } \\
\left(\mathrm{mg} / \mathrm{m}^{2} / \mathrm{yr}\right)(\%)\end{array}$} & \multicolumn{2}{|c|}{$\begin{array}{l}\text { Rattlesnake Springs } \\
\quad\left(\mathrm{mg} / \mathrm{m}^{2} / \mathrm{yr}\right)(\%)\end{array}$} \\
\hline & 2653.0 & 11.4 & 0.0 & 0.0 & 0.0 & 0.0 \\
\hline \multicolumn{7}{|l|}{ Collector } \\
\hline (TOTAL) & $(19444.4)$ & $(83.9)$ & $(12498.7)$ & $(88.4)$ & $(15416.9)$ & $(94.3)$ \\
\hline Gatherer & 15288.7 & 66.0 & 9322.1 & 65.9 & 3622.3 & 22.2 \\
\hline Filterer & 4155.7 & 17.9 & 3176.6 & 22.5 & 11794.6 & 72.1 \\
\hline Shredder & 638.9 & 2.8 & 1315.6 & 9.3 & 165.8 & 1.0 \\
\hline Predator & 448.8 & 1.9 & 328.6 & 2.3 & 767.6 & 4.7 \\
\hline (GRAND TOTAL) & $(23185,1)$ & $(100.0)$ & $(14142.9)$ & $(100.0)$ & $(16350.3)$ & $(100.0)$ \\
\hline
\end{tabular}


TABLE 18. Annual Production of Insect Trophic Levels in Douglas Creek, Snively Springs, and Rattlesnake Springs

\begin{tabular}{|c|c|c|c|c|c|c|}
\hline \multirow{2}{*}{$\frac{\begin{array}{c}\text { Trophic } \\
\text { Level }\end{array}}{\text { Herbivore }}$} & \multicolumn{2}{|c|}{$\begin{array}{l}\text { Douglas Creek } \\
\left(\mathrm{mg} / \mathrm{m}^{2} / \mathrm{yr}\right)(\%)\end{array}$} & \multicolumn{2}{|c|}{$\begin{array}{l}\text { Snively Springs } \\
(\mathrm{mg} / \mathrm{m} / \mathrm{yr})(\%) \\
\end{array}$} & \multicolumn{2}{|c|}{$\begin{array}{l}\text { Ratt lesnake Springs } \\
\left(\mathrm{mg} / \mathrm{m}^{2} / \mathrm{yr}\right)(\%)\end{array}$} \\
\hline & 2813.9 & 12.2 & 219.6 & 1.6 & 41.2 & 0.3 \\
\hline Detritivore & 19922.4 & 85.9 & 13594.7 & 96.1 & 15541.5 & 95.0 \\
\hline Carnivore & 448.8 & 1.9 & 328.6 & 2.3 & 767.6 & 4.7 \\
\hline (GRAND TOTAL) & $3185.1)$ & $(100.0)$ & 4142.9) & $00.0)$ & $16350.3)$ & 00.01 \\
\hline
\end{tabular}




\section{DISCUSSION}

ESTIMATING SECONDARY PRODUCTION

Benke et al. (1984) attempted to describe a methodological framework for other investigators to follow when estimating secondary production. They stressed the importance and difficulty of accurately estimating the CPI of each taxon within a benthic community. They suggested using laboratory growth data and life history data when direct field data were not available. I followed their framework when estimating secondary production. Many of my CPI estimates are based upon a review of the literature because of a lack of direct field data. These estimates may be refined as the body of information grows concerning larval development times of aquatic invertebrates. I have stated all assumptions clearly to aid investigators in this process.

Benke et al. (1984) also stressed the importance and value of estimating secondary production. They stated that production anaiysis, more than density or biomass, is the most meaningful way to anaiyze functional feeding groups in natural ecosystems. They then provided an example where the importance of gathering-collector invertebrates was underestimated by biomass analysis and overestimated by density analysis (e.g. in Douglas Creek, grazer-scraper importance was overestimated and collector importance was underestimated). My work provides another example of the importance of estimating secondary production to accurately describe the roles of organisms in streams and to understand ecosystem dynamics.

\section{COMPARISON BETWEEN STUDY STREAMS}

Insect Faunas

Similarities occurred between the aquatic insect faunas in Douglas Creek, Snively Springs, and Rattlesnake Springs. Dipterans, midges, and blackflies were very important in all study streams and accounted for $40 \%$ to $70 \%$ of the total annual community production. Also, several insect taxa had short development times and multiple cohorts in each of 
the study streams. Gray (1981) suggested that rapid development may be advantageous in streams subject to flash floods. Flash floods occur in a11 of the study streams [approximately every four years in Rattlesnake Springs (Cushing and Wolfe 1982)].

Functional Groups and Trophic Levels

The River Continuum Concept (RCC) provides a template to which various physical factors of a stream can be compared for predicting biotic responses (Vannote et al. 1980). An important factor affecting the stream biota is the amount of sunlight reaching the substrate for primary production. The amount of light is influenced by shading from riparian vegetation and instream autotrophs. The biota in Snively Springs and Rattlesnake Springs are greatly influenced by this interaction, as riparian vegetation and watercress shade much of the substrate. The substrate of Snively Springs and Rattlesnake Springs is mainly sand/silt (see Table 1), limiting the area available for algae to attach and grow. Based upon RCC assumptions, a lack of grazer-scrapers that rely on algae and periphyton as a food source would be expected. This occurred in Snively Springs and Rattlesnake Springs where grazerscrapers were completely absent.

Douglas Creek, however, is iarger and shading from riparian vegetation affected a smaller portion of the stream cross section. Watercress is limited to the stream banks, leaving more water open to receive sunlight. The substrate is rocky (see Table 1), which provides habitat for algae. As suggested by the RCC, grazer-scrapers are an important functional group.

The RCC predicts a significant proportion of shredders to be present when the riparian vegetation covers the stream and contributes large amounts of allochthonous detritus. However, shredders were of little importance in any of the streams I studied. The reasons for this are unclear and require further investigation. Cushing (in press) found the amount of allochthonous detritus entering these streams to be low, indicating a lack of food for shredders. Fisher and Gray (1983) found 
that shredders were virtually absent from the Sonoran Desert stream, Sycamore Creek, as was their food source of large particulate organic matter.

Detritivores were dominant in all study streams, indicating a large dependence upon detritus as a food source. Collecting (filtering and gathering) was the major feeding strategy used to obtain detritus, and collectors generally consume Fine Particulate Organic Matter (FPOM) (Merritt and Cummins 1984). The conclusion can then be inferred that detritus in the form of FPOM was the major food source of the insects in these study streams. This conclusion is supported by the results of my analyses of gut contents and the results of Cushing and Rader (1982).

COMPARISON WITH OTHER STREAMS

Annual $P / B$ ratios ranged from 3.6 to 121.7 for insects from the three study streams. The high annual $P / B$ ratios are attributed to insects with rapid development and multiple cohorts (e.g., many Chironomidae). The annual $P / B$ ratios that $I$ calculated for cold-desert streams are generally lower than those reported by Jackson and Fisher (1986) for Sonoran Desert stream insects and by Benke et al. (1984) for southeastern blackwater stream insects. Their study streams are warmer and insect development occurs faster, resulting in a greater number of cohorts. The annual $P / B$ ratios in my study were generally higher, however, than those reported by Krueger and Waters (1983) for northern temperate streams. Northern temperate streams are generally cooler and insect development occurs at a slower rate with fewer cohorts.

Community production rates ranged from 14 to $23 \mathrm{~g} \mathrm{ow} / \mathrm{m}^{2} / \mathrm{yr}$ in my three study streams. These rates are lower than the 50 to $70 \mathrm{~g} \mathrm{DW} / \mathrm{m}^{2} / \mathrm{yr}$ in southeastern blackwater streams (Nelson and Scott 1962, Benke et al. 1984), and much lower than in the Sonoran Desert stream, Sycamore Creek, where community production exceeded $120 \mathrm{~g} \mathrm{DW} / \mathrm{m}^{2} / \mathrm{yr}$ (Fisher and Gray 1983, Jackson and Fisher 1986). However, the rates reported here are 
generally higher than the 5 to $15 \mathrm{~g} \mathrm{DW} / \mathrm{m}^{2} / \mathrm{yr}$ reported for northern temperate streams (Fisher and Likens 1973, Neves 1979, Krueger and Waters 1983).

\section{CONCLUSIONS}

In conciusion, I want to stress the most important findings of my investigation.

1) Taxa with short development times and multiple cohorts, such as midges and blackflies, are very important to cold-desert strearns in terms of total production. This life history strategy may be advantageous in streams such as the ones $I$ studied, where flash floods occur.

2) Insects in cold-desert streams depend largely on detritus as a food source and obtain it mainly by collecting (filtering and gathering).

3) Community production rates in cold-desert streams are generally higher than in northern temperate streams, lower than in southeastern blackwater streams, and much lower than in Sonoran Desert streams. Stream temperature is an important factor (maybe the most important) in controlling production rates and causing rates to differ across physiographic regions .

4) Investigators should calculate secondary production, not density or biomass, to accurately assess the roles of organisms in aquatic ecosystems. In Douglas Creek, for example, collector and grazer-scraper importance was misrepresented by density and biomass analysis.

5) The framework given by Benke et al. (1984) to estimate secondary production provides a workable process, and if followed in other studies, will make comparisons between streams more meaningful. 
More research needs to be conducted on cold-desert streams before their ecology is fully understood. This study provides a significant piece to the complex puzzle of these unique ecosystems. 
• 


\section{REFERENCES}

Anderson, R. 0. 1959. A modified flotation technique for sorting bottom fauna samples. Limnology and Oceanography 4:223-225.

Becker, C. D. 1973. Development of Simulium vittatum Zett. (Diptera: Simuliidae) from larvae to adults at thermal increments from 17.0 to 27.0 C. American Midland Naturalist 89:246-251.

Behmer, D. J. and C. P. Hawkins. 1986. Effects of overhead canopy on macroinvertebrate production in a Utah stream. Freshwater Biology 16:287-300.

Benke, A. C. and J. B. Waide. 1977. In defense of average cohorts. Freshwater Biology 7:61-63.

Benke, A. C. 1979. A modification of the Hynes method for estimating secondary production with particular significance for multivoltine populations. Limnology and Oceanography 24:168-171.

Benke, A. C. and J. B. Wallace. 1980. Trophic basis production among netspinning caddisflies in a southern Appalachian stream. Ecology 61:108-118.

Benke, A. C., T. C. VanArsdall Jr. and D. M. Gillespie. 1984. Invertebrate productivity in a subtropical blackwater river: importance of habitat and iffe history. Ecological Monographs 54:25-63.

Clifford, H. F. 1982. Life cycles of mayflies (Ephemeroptera), with special reference to voltinism. Quaestiones Entomologicae 18:15-90.

Cummins, K. W. 1962. An evaluation of some techniques for the collection and analysis of benthic samples with special emphasis on lotic waters. American Midland Naturalist 67:477-504.

Cushing, C. E., C. D. Mcintire, J. R. Sedell, K. W. Cummins, G. W. Minshall, R. C. Peterson and R. L. Vannote. 1980. Comparative study of physical-chemical variables of streams using multivariate analysis. Archiv fur Hydrobiologie $89: 343-352$.

Cushing, C. E. and R. T. Rader. 1982. A note on the food of Callibaetis (Epheneroptera:Baetidae). Great Basin Naturalist 41:431-432.

Cushing, C. E. and E. G. Wolf. 1982. Organic energy budget of Rattlesnake Springs, Washington. American Midland Naturalist 107:404-407.

Cushing, C. E. and E. G. Wolf. 1984. Primary production in Rattlesnake Springs, a cold-desert spring-stream. Hydrobiologia 114:229-236.

Cushing, C. E. Allochthonous detritus input to a small, cold desert springstream. Verhandlungen Internationale Vereinigung Limnologie 23:(in press). 
Fisher, S. G. and G. E. Likens. 1973. Energy flow in Bear Brook, New Hampshire: an integrative approach to stream ecosystem metabolism. Ecological Monographs 43:421-439.

Fisher, S. G. and L. J. Gray. 1983. Secondary production and organic matter processing by collector macroinvertebrates in a desert stream. Ecology $64: 1217-1224$.

Gray, L. J. 1981. Species composition and life histories of aquatic insects in a lowland Sonoran desert stream. American Midland Naturalist 106:229-242.

Hamilton, A. L. 1969. On estimating annual production. Limnology and Oceanography 14:771-782.

Hynes, H. B. N. and M. J. Coleman. 1968. A simple method of assessing the annual production of stream benthos. Limnology and Oceanography 13:569-573.

Hynes, H. B. N. 1970. "The Ecology of Running Waters." University of Toronto Press, Ontario, Canada.

Hynes, H. B. N. 1980. A name change in the secondary production business. Limnology and Oceanography 25:778.

Jackson, J. K. and S. G. Fisher. 1986. Secondary production, emergence, and export of aquatic insects of a Sonoran desert stream. Ecology 67:629-638.

Krueger, C. C. and T. F. Waters. 1983. Annual production of macroinvertebrates in three streams of different water quality. Ecology 64:840-850.

Mackey, A. P. 1977. Growth and development of larval Chironomidae. 0ikos $28: 270-275$.

McAuliffe, J. R. 1982. Behavior and life history of Leucotrichia pictipes (Banks) (Trichoptera: Hydroptilidae) with special emphasis on case reoccupancy. Canadian Journal of Zoology 60:1557-1561.

McCullough, D. A., G. W. Minshall and C. E. Cushing. 1979. Bioenergetics of a stream "collector" organism, Tricorythodes minutus (Insecta:

Ephemeroptera). Limnology and Oceanography 24:45-58.

Merritt, R. W. and K. W. Cumrnins. 1984. "An Introduction to the Aquatic Insects of North America." 2nd Ed. Kendal1/Hunt Publishing Company, Dubuque, Iowa.

Nelson, D. J. and D. C. Scott. 1962. Role of detritus in the productivity of a rock out-crop community in a Piedmont stream. Limnology and Oceanography $7: 396-413$.

Neves, R. J. 1979. Secondary production of epilithic fauna in a woodland stream. American Midland Naturalist 102:209-224. 
0'Hop, J., J. B. Wallace and J. D. Haefer. 1984. Production of a stream shredder, Peltoperla maria (Plecoptera: Peltoperlidae) in disturbed and undisturbed hardwood catchments. Freshwater Biology 14:13-21.

Smock, L. A., E. Gilinsky and D. L. Stoneburner. 1985. Macroinvertebrate production in a southwestern United States blackwater stream. Ecology 66:1491-1503.

Vannote, R. L., G. W. Minshall, K. W. Cummins, J. R. Sedell and C. E. Cushing. 1980. The River Continuum Concept. Canadian Journal of Fisheries and Aquatic Sciences 37:130-137.

Waters, T. F. 1977. Secondary production in inland waters. Advances in Ecological Research 10:91-164.

Waters, T. F. and J. C. Hokenstrom. 1980. Annual production and drift of the st ream amphipod Gammarus pseudolimnaeus in Valley Creek, Minnesota. Limnology and 0ceanography 25:700-710.

Welch, P. S. 1935. "Limnology." McGraw-Hill, New York and London. 


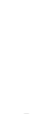

,

. 


\section{APPENDIX}

INSECTS FOUND IN DOUGLAS CREEK, SNIVELY SPRINGS, AND RATTLESNAKE SPRINGS 
INSECTS FOUND IN DOUGLAS CREEK, SNIVELY SPRINGS, AND RATTLESNAKE SPRINGS

\author{
DOUGLAS CREEK \\ Diptera \\ Chi ronomidae \\ Brilla flavifrons sp. \\ Chaetocladius sp. \\ Chironomus sp. \\ Heleniella sp. \\ Parametriocnemus sp. \\ Phaenospectra sp. \\ Polypedilum sp. \\ Thienemannimyia sp. \\ Empididae \\ Simuliidae \\ Simulium sp. \\ Tabanidae \\ Tipulidae \\ Trichoptera \\ Hydroptilidae \\ Leucotrichia pictipes \\ Hydropsychidae \\ Cheumatopsyche sp. \\ Hydropsyche sp. \\ Coleoptera \\ Elmidae \\ Optioservus sp.
}






SNIVELY SPRINGS

\author{
Diptera \\ Chi ronomidae \\ Chaetocladius sp. \\ Chironomus sp. \\ Heleniella sp. \\ Polypedilum sp. \\ Thienemannimyia sp. \\ Dixidae \\ Empididae \\ Simuli idae \\ Simulium sp. \\ Tabanidae \\ Tipulidae
}




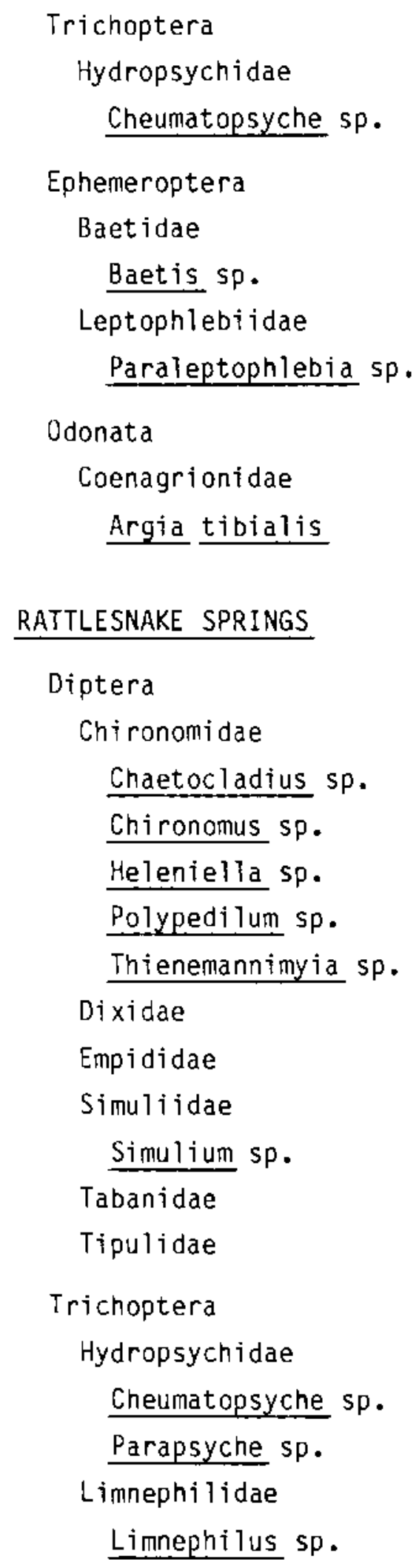




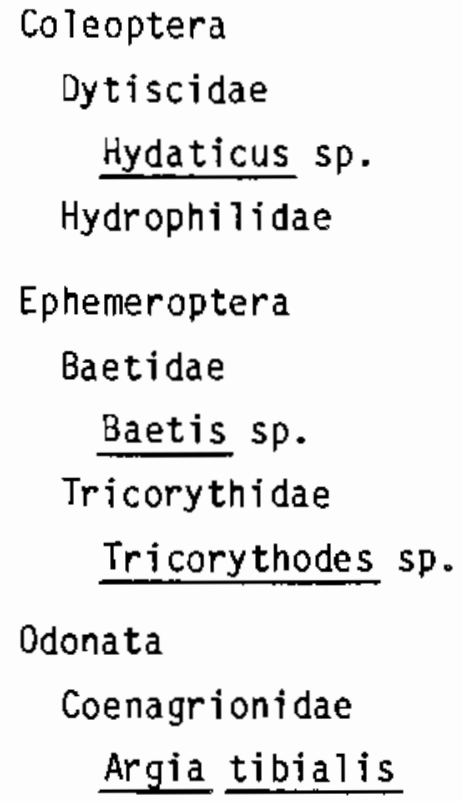




\section{DISTRIBUTION}

No. of

Copies

DFFSITE

30 DOE Technical Information Center

J. D. Allan

Department of Zoology

University of Maryland

College Park, MD 20742

N. Anderson

Department of Entomology

Oregon State University

Corvallis, OR 97331

B. Barker

Department of Biology

Centra] Washington University

Ellensburg, WA 98926

J. Barnes

Department of Zoology

Brigham Young University

Provo, UT 84602

A. C. Benke

Department of Biology

University of Alabama

Tuscaloosa, AL 35486

E. F. Benfield

Department of Biology

VPI and State University

Blacksburg, VA 24061
A. Brown
Zoology Department
University of Arkansas
Fayetteville, AR 72701
D. A. Bruns
Environmental Sciences Section
P.0. Box 1625
Idaho Falls, ID 83415

No. of

Copies
H. F. Clifford

Department of Zoology

University of Alberta

Edmonton, Alberta

CANADA T6G $2 E 3$

W. Coffman

Department of Life Sciences

University of Pittsburgh

Pittsburgh, PA 15260

S. Cooper

Department of Biological

Sciences

University of California

Santa Barbara, CA 93106

A. Covich

Zoology Department

University of Oklahoma

Norman, OK 73019

K. Cummins

Appalachian Environmenta)

Laboratory

University of Maryland

Frostburg, MD 21532

D. Dudgeon

Department of Zoology

University of Hong Kong

HONG KONG

P. Dumas

Department of Biology

Central Washington University

Ellensburg, WA 98926

J. W. Elwood

Environmental Sciences Division

Oak Ridge National Laboratory

Building 2001

Oak Ridge, TN 37830 
No. of

Copies

S. Fisher

Department of Zoology

Arizona State University

Tempe, AZ 85281

10 W. L. Gaines

P.0. Box 428

Winthrop, WA 98862

S. Gregory

Department of Fisheries and Wild ife

Oregon State University

Corvallis, OR 97331

M. Gurtz

Water Resources Division

U.S. Geological Survey

P.0. Box 2857

Raleigh, NC $276 \mathrm{D} 2$

D. Hart

Academy of Natural Sciences

19 th and The Parkway

Philadelphia, PA 19103

$R$. Hauer

Flathead Lake Biological Station

East Shore

Bigfork, MT 59911

C. Hawkins

Department of Fisheries and Wildlife

Utah State University - UMC52

Logan, UT 84322

N. Hedges

Bureau of Land Management

Wenatchee, WA 98801

B. Hilger

Research Institute for Nature Management

P. 0 . Box 46

3956 ZR Leersum

THE NETHERLANDS
No. of

Copies

H. B. N. Hynes

Department of Biology

University of Waterloo

Waterloo, Ontario

CANADA N2L $3 G 1$

S. Jackson

639 Crestview Dr.

Moses Lake, WA 98837

P. S. Lake

Department of Zoology

Monash University

Clayton

Victoria 3168

AUSTRALIA

G. Lambert $i$

Department of Fisheries and Wildlife

Oregon State University

Corvallis, OR 97331

R. Mackay

Department of Zoology

University of Toronto

Toronto, Ontario

CANADA M5S IAl

G. R. Marzolf

Division of Biology

Kansas State University

Manhattan, KS 665D6

R. Merritt

Department of Entomology

Michigan State University

East Lansing, MI 48824

G. W. Minshall

Department of Biology

Idaho State University

Pocatello, ID 83209

M. Oswood

Department of Biology

University of Alaska

Fairbanks, AK 99701 
No. of

Copies

\section{B. Peckarsky \\ Department of Entomology \\ Cornell University \\ Ithaca, NY 14853 \\ I. Pettman, Librarian \\ Freshwater Biological \\ Association \\ The Ferry House \\ Ambleside \\ Cumbria LS22 OLP \\ ENGLAND \\ R. Petersen \\ Department of Limnology \\ University of Lund \\ S-22003 Lund \\ SWEDEN}

S. R. Reice

Department of Zoology

University of Northern Carolina

Chapel Hill, NC 27514

V. Resh

Department of Entomology

University of California

Berkeley, CA 94720

3. Sedell

Forest Sciences Laboratory, USFS

Oregon State University

Corvallis, OR 97331

A. L. Sheldon

Department of Zoology

University of Montana

Missoula, MT 59812

10 S. Smith

Department of Biology

Central Washington University

Ellensburg, WA 98926
No. of

Copies

\author{
J. Stanford \\ Flathead Lake Biological \\ Station \\ East Shore \\ Bigfork, MT 59911 \\ B. Statzner \\ Zoolog. Inst. d. Univ. (T.H.) \\ Kornblumenstr. 13 \\ Postfach 6380 \\ 7500 Karlstuhel \\ FEDERAL REPUBLIC OF GERMANY
}

B. Sweeney

Stroud Water Research Center

RD \#1, Box 512

Avondale, PA 19311

R. Vannote

Stroud Water Research Center

RD *1, Box 512

Avondale, PA 19311

J. B. Wallace

Department of Entomology

University of Georgia

Athens, GA 30602

G. M. Ward

Department of Biology

University of Alabama

Tuscaloosa, AL 35486

J. Ward

Department of Zoology and Entomology

Colorado State University

Fort Collins, CD 80523

T. Waters

Department of Entomology, Fisheries and Wildlife

University of Minnesota

St. Paul, MN 55455 
No. of

Copies

U. Webster

Department of Biology

VPI and State University

Blacksburg, VA 24061

C. Wiberg

Department of Biology

Central Washington University

Ellensburg, WA 98926

M. Winterbourn

Department of Zoology

University of Canterbury

Christchurch

NEW ZEALAND

ONSITE

DOE Richland Dperations Office

J. J. Sutey

48 Pacific Northwest Laboratory

C. D. Becker

C. E. Cushing (25)
No, of

Copies

Pacific Northwest Laboratory

(contd)

D. D. Dauble

D. W. Dragnich

D. H. Fickeisen

M. J. Graham

J. M. Hales

$P . C$. Hays

P. J. Mellinger

D. A. Neitzel

R. L. Newell

T. L. Page

T. M. Poston

W. H. Rickard

L. E. Rogers

J. A. Stott lemyre

R. E. Wildung

Publishing Coordination (2)

Technical Report Files (5) 